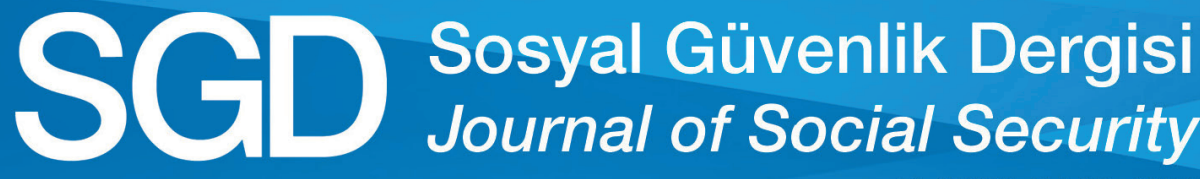 \\ P-ISSN: 2146-4839 \\ E-ISSN: 2148-483X
}

\section{Engelli İstihdamına Yönelik Hazırlanan Kamu Spotu Reklamları: Amerika Birleşik Devletleri Çalışma Bakanlığı Üzerine İnceleme}

\section{The Public Spot Advertisements Regarding Disability Employment: An Examination on United States Department of Labor (DOL)}

\author{
Mehmet Ali GAZI
}

Trabzon Üniversitesi, İletişim Fakültesi

\section{Caner ÇAKI}

İnönü Üniversitesi, İletişim Fakültesi

Aralık 2019, Cilt 9, Sayı 2, Sayfa 409-430

December 2019, Volume 9, Issue 2, Page 409-430

P-ISSN: 2146-4839

E-ISSN: $2148-483 \mathrm{X}$

2019-2

e-posta: sgd@sgk.gov.tr

Yazılar yayınlanmak üzere kabul edildiği takdirde, SGD elektronik ortamda tam metin olarak yayımlamak da dahil olmak üzere, tüm yayın haklarına sahip olacaktır. Yayınlanan yazılardaki görüşlerin sorumluluğu yazarlarına aittir. Yazı ve tablolardan kaynak gösterilerek alıntı yapılabilir.

If the manuscripts are accepted to be published, the SGD has the possession of right of publicationand the copyright of the manuscripts, included publishing the whole text in the digital area. Articles published in the journal represent solely the views of the authors.

Some parts of the articles and the tables can be citeded by showing the source. 
Cilt: 9 - Say1: 2 - Y11: 2019

Volume: 9 - Issue: 2 - Year: 2019

P-ISSN: 2146-4839

E-ISSN: 2148-483X

Sahibi / Owner of the Journal

Sosyal Güvenlik Kurumu Adına / On behalf of the Social Security Institution

Dr. Mehmet Selim BAĞLI

(Kurum Başkan1 / President of the Institution)

Sorumlu Yazı İșleri Müdürü / Responsible Publication Manager

Uğur KORKMAZ

Yayın Kurulu / Editorial Board

Cevdet CEYLAN

Eyüp Sabri DEMIRCI

Nazmi DOĞAN

Erdal YILMAZ

Okan AYAZ

Editörler / Editors

Doç. Dr. Erdem CAM

Selda DEMIR

Redaksiyon / Redaction

Nihan ERTÜRK

Yayın Türü: Uluslararası Süreli Yayın / Type of Publication: International Periodical

Yayın Aralığı: 6 aylık / Frequency of Publication: Twice a Year

Dili: Türkçe ve İngilizce / Language: Turkish and English

Basım Tarihi / Press Date: 19.12.2019

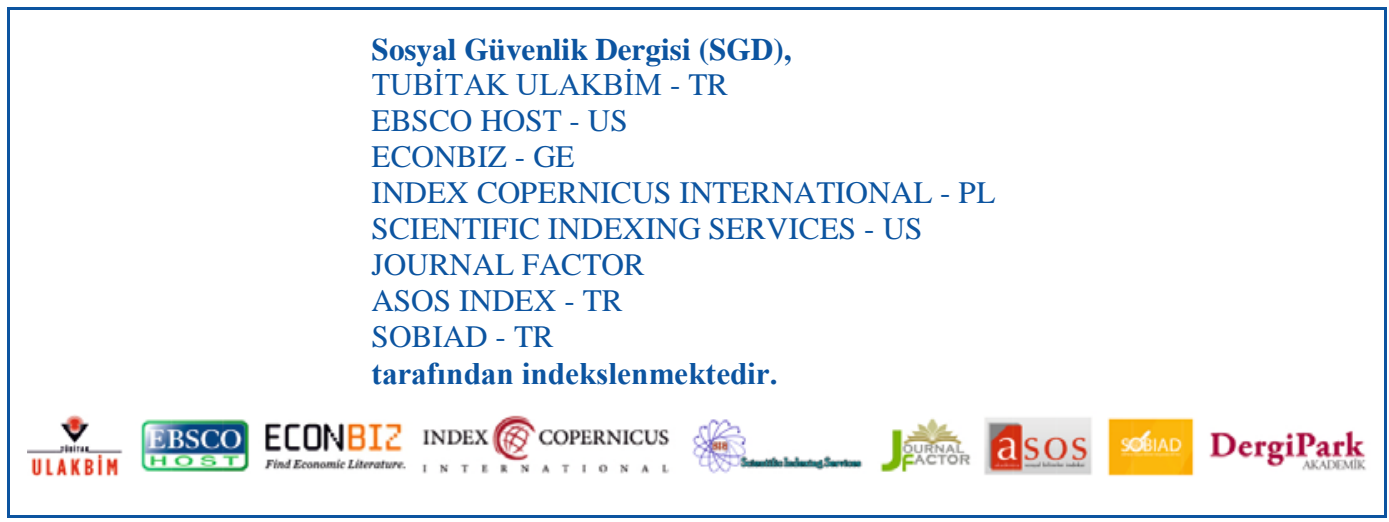

(C) Tüm hakları saklıdır. Sosyal Güvenlik Dergisi'nde yer alan bilimsel çalışmaların bir kısmı ya da tamamı telif hakları saklı kalmak üzere eğitim, araştırma ve bilimsel amaçlarla çoğaltılabilir.

Tasarım / Design: PERSPEKTIF Matbaacılık Tasarım Tic.Ltd.Şti. (0 312) 3842055 - Ankara

Basım Yeri / Printed in: PERSPEKTIF Matbaacılık Tasarım Tic.Ltd.Şti. (0 312) 3842055 - Ankara

İletişim Bilgileri / Contact Information

Sosyal Güvenlik Kurumu Başkanlığı

Ziyabey Caddesi No: 6 Balgat / Ankara / TÜRKIYE

Tel / Phone: +90 3122078891 - 2078770 - Faks / Fax: +90 3122077819

Erişim/Webpage: http://www.sgk.gov.tr/wps/portal/sgk/sgd/tr - e-posta / e-mail: sgd@sgk.gov.tr 
Professor Yener ALTUNBAŞ

Bangor University - UK

Professor Paul Leonard GALLINA

Bishop’s University - CA

Professor Jacqueline S.ISMAEL

University of Calgary - CA
Professor Özay MEHMET

University of Carleton - CA

Professor Allan MOSCOVITCH

University of Carleton - CA

Professor Mark THOMPSON

University of British Columbia - CA
Asst. Prof. Sara HSU

State University of New York- USA

Asst. Prof. C. Rada Von ARNIM

University of Utah - USA

\section{ULUSAL DANISMA KURULU / NATIONAL ADVISORY BOARD}

Prof. Dr. Ahmet Cevat ACAR

İstanbul Üniversitesi

İşletme Fakültesi

Prof. Dr. İsmail AĞIRBAŞ

Ankara Üniversitesi

Sağlık Bilimleri Fakültesi

Prof. Dr. Levent AKIN

Ankara Üniversitesi

Hukuk Fakültesi

Prof. Dr. Yusuf ALPER

Bursa Uludağ Üniversitesi

İktisadi ve İdari Bilimler Fakültesi

Prof. Dr. Faruk ANDAÇ

Çă̆ Üniversitesi

Hukuk Fakültesi

Prof. Dr. Kadir ARICI

Ankara Hacı Bayram Veli Üniversitesi

Hukuk Fakültesi

Prof. Dr. Onur Ender ASLAN

Ankara Sosyal Bilimler Üniversitesi

Siyasal Bilgiler Fakültesi

Prof. Dr. Zakir AVȘAR

Ankara Hacı Bayram Veli Üniversitesi

İletișim Fakültesi

Prof. Dr. Ufuk AYDIN

Anadolu Üniversitesi

Hukuk Fakültesi

Prof. Dr. Abdurrahman AYHAN

Kıbrıs İlim Üniversitesi

Hukuk Fakültesi

Prof. Dr. Serpil AYTAC

Bursa Uludağ Üniversitesi

İktisadi ve İdari Bilimler Fakültesi

Prof. Dr. Mehmet BARCA

Ankara Sosyal Bilimler Üniversitesi

Siyasal Bilgiler Fakültesi

Prof. Dr. Süleyman BAȘTERZI

Ankara Üniversitesi

Hukuk Fakültesi

Prof. Dr. Nursen CANIKLİOĞLU

Marmara Üniversitesi

Hukuk Fakültesi

Prof. Dr. Fevzi DEMIR

Yaşar Universitesi

Hukuk Fakültesi
Prof. Dr. A. Murat DEMIRCIOĞLU

Yıldız Teknik Üniversitesi

İktisadi ve İdari Bilimler Fakültesi

Prof. Dr. Ömer EKMEKÇİ

İstanbul Üniversitesi

Hukuk Fakültesi

Prof. Dr. E. Murat ENGIiN

Galatasaray Üniversitesi

Hukuk Fakültesi

Prof. Dr. Hediye ERGIN

Marmara Üniversitesi

İktisat Fakültesi

Prof. Dr. Sükran ERTÜRK

Dokuz Eylül Üniversitesi

Hukuk Fakültesi

Prof. Dr. Afsun Ezel ESATOĞLU

Ankara Üniversitesi

Sağlık Bilimleri Fakültesi

Prof. Dr. Ali GÜZEL

Kadir Has Üniversitesi

Hukuk Fakültesi

Prof. Dr. Alpay HEKIMLER

Tekirdağ Namık Kemal Üniversitesi

İktisadi ve İdari Bilimler Fakültesi

Prof. Dr. Oğuz KARADENIZ

Pamukkale Üniversitesi

İktisadi ve İdari Bilimler Fakültesi

Prof. Dr. Aşkın KESER

Bursa Uludağ Üniversitesi

İktisadi ve İdari Bilimler Fakültesi

Prof. Dr. Cem KILIC

TOBB Ekonomi ve Teknoloji Üniversites İktisadi ve İdari Bilimler Fakültesi

Prof. Dr. Ali Riza OKUR

İstanbul Sabahattin Zaim Üniversitesi Hukuk Fakültesi

Prof. Dr. Serdar SAYAN

TOBB Ekonomi ve Teknoloji Üniversitesi

İktisadi ve İdari Bilimler Fakültesi

Prof. Dr. Ali Nazım SÖZER

Yaşar Üniversitesi

Hukuk Fakültesi

Prof. Dr. Sarper SÜZEK

At1lım Universites

Hukuk Fakültesi
Prof. Dr. Müjdat SAKAR

Marmara Üniversitesi

İktisat Fakültes

Prof. Dr. Savas TASSKENT

İstanbul Teknik Üniversitesi

İşletme Fakültesi

Prof. Dr. Ferda YERDELEN TATOĞLU

İstanbul Üniversitesi

İktisat Fakültesi

Prof. Dr. Sabri TEKIR

İzmir Demokrasi Üniversitesi

İktisadi ve İdari Bilimler Fakültesi

Prof. Dr. Mehmet TOP

Hacettepe Üniversitesi

İktisadi ve İdari Bilimler Fakültesi

Prof. Dr. Türker TOPALHAN

Ankara Hacı Bayram Veli Üniversitesi

İktisadi ve İdari Bilimler Fakültesi

Prof. Dr. Aziz Can TUNCAY

Bahçeșehir Üniversitesi

Hukuk Fakültesi

Prof. Dr. M. Fatih UȘAN

Ankara Yıldırım Beyazıt Üniversitesi

Hukuk Fakültesi

Doç. Dr. Gaye BAYCIK

Ankara Üniversitesi

Hukuk Fakültesi

Doc. Dr. Emel İSLAMOGLU

Sakarya Üniversitesi

Siyasal Bilgiler Fakültesi

Doç. Dr. Saim OCAK

Marmara Üniversitesi

Hukuk Fakültesi

Doç. Dr. Ercüment ÖZKARACA

Marmara Üniversitesi

Hukuk Fakültesi

Doc. Dr. Gülbiye YENIMAHALLELİ

Ankara Üniversitesi

Sağlık Bilimleri Fakültesi

Doc. Dr. Sinem YILDIRIMALP

Sakarya Üniversitesi

Siyasal Bilgiler Fakültesi 
Prof. Dr. Levent AKIN

Ankara Üniversitesi

Hukuk Fakültesi

Prof. Dr. Yusuf ALPER

Bursa Uludağ Üniversitesi

İktisadi ve İdari Bilimler Fakültesi

Prof. Dr. Özgür ASLAN

İstanbul Üniversitesi

Sağlık Bilimleri Fakültesi

Prof. Dr. Murat ATAN

Ankara Hacı Bayram Veli Üniversitesi

İktisadi ve İdari Bilimler Fakültesi

Prof. Dr. Sibel ATAN

Ankara Haci Bayram Veli Üniversitesi İktisadi ve İdari Bilimler Fakültesi

Prof. Dr. Berrin CEYLAN ATAMAN Altınbaş Üniversitesi

İktisadi, İdari ve Sosyal Bilimler Fakültesi

Prof. Dr. Özlem ATAY

Ankara Üniversitesi

Siyasal Bilgiler Fakültesi

Prof. Dr. Ufuk AYDIN

Anadolu Üniversitesi

Hukuk Fakültesi

Prof. Dr. Hakan BERUMENT

Bilkent Üniversitesi

İktisadi, İdari ve Sosyal Bilimler Fakültesi

Prof. Dr. Özlem ÇAKIR

Dokuz Eylül Üniversitesi

İktisadi ve İdari Bilimler Fakültesi
Prof. Dr. Kamil ORHAN

Pamukkale Üniversitesi

İktisadi ve İdari Bilimler Fakültesi

Prof. Dr. Fatma Füsun ERDEN

Ankara Üniversitesi

Prof. Dr. Şenay GÖKBAYRAK

Ankara Üniversitesi

Siyasal Bilgiler Fakültesi

Prof. Dr. Nuray GÖKÇEK KARACA

Anadolu Üniversitesi

Sağlık Bilimleri Fakültesi

Prof. Dr. Deniz KAĞNICIOĞLU

Anadolu Üniversitesi

Prof. Dr. Handan KUMAS

Pamukkale Üniversitesi

İktisadi ve İdari Bilimler Fakültesi

Prof. Dr. Faruk SAPANCALI

Dokuz Eylül Üniversitesi

İktisadi ve İdari Bilimler Fakültesi

Prof. Dr. Hasan ȘAHIN

Ankara Üniversitesi

Siyasal Bilgiler Fakültesi

Prof. Dr. Suat UĞUR

Çanakkale Onsekiz Mart Üniversitesi

Biga İktisadi ve İdari Bilimler Fakültesi

Prof. Dr. Yücel UYANIK

Ankara Haci Bayram Veli Üniversitesi

İktisadi ve İdari Bilimler Fakültesi
Ziraat Fakültesi

İktisadi ve İdari Bilimler Fakültesi
Prof. Dr. Erinç YELDAN

Bilkent Üniversitesi

İktisadi İdari ve Sosyal Bilimler Fakültesi

Prof. Dr. Handan YOLSAL

İstanbul Üniversitesi

İktisat Fakültesi

Prof. Dr. Sayım YORĞUN

İstanbul Üniversitesi

İktisat Fakültesi

Doc. Dr. Erdem CAM

Ankara Üniversitesi

Siyasal Bilgiler Fakültesi

Doç. Dr. Emel İSLAMOĞLU

Sakarya Üniversitesi

Siyasal Bilgiler Fakültesi

Doç. Dr. Özgür TOPKAYA

Çanakkale Onsekiz Mart Üniversitesi Biga İktisadi ve İdari Bilimler Fakültesi

Doç. Dr. M. Çağlar ÖZDEMIR

Sakarya Üniversitesi

Siyasal Bilgiler Fakültesi

Dr. Öğr. Üyesi Atalay ÇAĞLAR

Pamukkale Üniversitesi

İktisadi ve İdari Bilimler Fakültesi

Dr. Öğr. Üyesi Nagihan DURUSOY ÖZTEPE

Pamukkale Üniversitesi

İktisadi ve İdari Bilimler Fakültesi 


\section{SAYI DEĞERLENDİRME İSTATISTIKLERİ}

EVALUATION STATISTICS FOR THIS ISSUE

Toplam gelen makale başvurusu

Number of received manuscript

Yayına kabul edilen makale sayıs1

Number of accepted manuscript

Hakem süreci devam eden makale sayısı

Under consideration

Red edilen makale sayısı

Rejected after evaluation

20

Ön inceleme aşamasında red edilen makale sayısı

Rejected before evaluation

12

Makale kabul oranı

Accepted manuscript rate

$\% 28$ 
1- Sosyal Güvenlik Dergisi (SGD), yılda iki kez yayınlanan uluslararası, hakemli, bilimsel bir dergidir.

2- Dergiye gönderilen yazılar başka bir yerde yayınlanmamış ya da yayınlanmak üzere gönderilmemiş olmalıdır.

3- Dergide yayınlanmasına karar verilen yazıların, elektronik ortamda tam metin olarak yayınlanmak da dahil olmak üzere, yayın hakları SGK'ya aittir.

4- Yayınlanmak üzere dergiye gönderilen yazılar önce Yayın Kurulunca dergi ilkelerine uygunluk açısından incelenir. Uygunluğu tespit edilen yazılar değerlendirmeleri için yazının ilgili olduğu alanda iki hakeme gönderilir. Hakem raporuna göre; yazarına düzeltme gönderilir, yayınlanır ya da reddedilir.

5- Yayınlanan yazılardaki görüşlerin sorumluluğu yazarlarına aittir. Yayınlanan makaleler atıf yapılmadan kullanılamaz.

6- Dergide yarg1 kararı incelemelerine yer verilebilir.

7- Yazıları yayınlanan yazarlara "Kamu Kurum ve Kuruluşlarınca Ödenecek Telif ve İşleme Ücretleri Hakkında Yönetmelik" çerçevesinde telif ücretleri ödenecektir.

8- SGD Sosyal Güvenlik Dergisi'ne makale gönderenler derginin yayın ilkelerini kabul etmiş sayılırlar.
1- Journal of Social Security is an international, peer reviewed, scientific journal published twice a year.

2- The papers submitted to Journal of Social Security must be unpublished in elsewhere or not synchronically be in the review process of another publication.

3- Social Security Institution and Journal of Social Security own the copyright of the papers published (written and electronic versions).

4- All manuscripts firstly evaluated by Editorial Board and send two independent referees. According to referees' reports, article will be sent to the authors to revise, publish or reject.

5- All the opinions written in articles are under responsilities of the authors. The published contents in the articles cannot be used without being cited.

6- Case review and commentaries are accepted by SGD.

7- Royalty fees will be paid to the authors whose articles published in the Journal of Social Security (SGD) in accordance with the related regulation.

8- Those who send articles to the SGD are considered to have accepted the publication principles of the SGD.

SGD, Sosyal Güvenlik Kurumunun faaliyet alanına, sosyal güvenlik, sosyal politika ve endüstri ilişkileri disiplinine katkısı olabilecek her alanda çalışmalara yer vererek, ülkemizin düşünsel birikimine katkıda bulunmak, toplumda sosyal güvenlik ve sosyal politika bilincini geliştirmek, geleceğe dönük hedef ve beklentileri ortak bir noktada buluşturmak amacıyla yayınlanmaktadır.

SGD, is being published in all areas related social security, social policy and industrial relations to make contribution intellectual life of Turkey, develop the social security and social policy consciousness and bring together the future targets and expectations on the common point of the society. 
İnceleme Makalesi - Review Article

\section{Engelli İstihdamına Yönelik Hazırlanan Kamu Spotu Reklamları: Amerika Birleşik Devletleri Çalışma Bakanlığı Üzerine İnceleme}

\section{The Public Spot Advertisements Regarding Disability Employment: An Examination on United States Department of Labor (DOL)}

\author{
Mehmet Ali GAZI ${ }^{*}$ \\ ORCID ID: 0000-0002-9239-4187 \\ Caner ÇAKI** \\ ORCID ID: 0000-0002-1523-4649
}

\author{
Sosyal Güvenlik Dergisi / Journal of Social Security \\ Cilt: 9 Sayı: 2 Y1l: 2019 /Volume: 9 Issue: 2 Year: 2019 \\ Sayfa Aralığı: 409-430 / Pages: 409-430 \\ DOI: $10.32331 /$ sgd.658885
}

\section{ÖZ}

Son yıllarda dünya genelinde engelli bireylerin istihdamına yönelik pek çok yasanın yürürlüğe girdiği görülmektedir. Yürürlüğe giren bu yasalar kapsamında işverenler, engelli bireylerin çalıştırmaları konusunda teşvik edilmektedir. Diğer yandan engelli istihdamına yönelik hazırlanan kamu spotu reklamları ile de engellilerin çalışma hayatına kazandırılması amaçlanmaktadır. Özellikle yakın zamanda Amerika Birleşik Devletleri Çalışma Bakanlığının desteğiyle hazırlanan "What can you do?/Ne yapabilirsin?" isimli reklam kampanyası engelli istihdamı konusunda gerek ulusal gerekse uluslararası alanda farkındalık oluşturulmasında önemli bir rol oynamıştır. Bu çalışmada "Ne yapabilirsin?" başlıklı reklam kampanyasında, engelli istihdamını arttırma amaciyla engelli bireylerin nasil ve ne şekilde kamu spotu reklamlarında sunulduğu ortaya konulmaya çalışılmıştır. Çalışma kapsamında nitel araştırma yöntemlerinden göstergebilimsel analiz yöntemi kullanılmıştır. Çalışmada incelenen kamu spotu reklamları, İsviçreli dilbilimci Ferdinand de Saussure'ün Göstergeler Modeli ışığında analiz edilmiştir. Çalışmada elde edilen bulgularda, kamu spotu reklamlarında engellilerin istihdama katkıları olmadığı yönündeki olumsuz mitlerin ortadan kaldırılarak, aksine istihdamın önemli bir parçası oldukları şeklinde olumlu mitlerin inşa edilmeye çalışıldığı ortaya çıkarılmıştır.

Anahtar Sözcükler: Engelli, istihdam, engelli istihdamı, kamu spotu, reklam

\begin{abstract}
In recent years, it has been observed that many laws have been put into effect worldwide for the employment of disabled citizens. Within these laws, employers have been encouraged to employ disabled citizens. On the other hand, it is aimed to bring the disabled citizens to the working life by public spot advertisements prepared for the disability employment. Especially the advertising campaign "What can you do?" prepared with the support of Department of Labor in United States played an important role in raising awareness on the employment of disabilities in both national and international areas. In the study, it was tried to show how and in what way the disabled citizens are presented in public spot ads in order to increase the employment of disabled people at the advertising campaign "What can you do?". In this study, semiotic analysis method in qualitative research methods was used. The public spot ads examined in the study were analyzed in the light of the Indicators Model of the Swiss linguist Ferdinand de Saussure. In the findings obtained in the study, it was revealed that positive myths that disabilities are an important part of employment were attempted to be constructed by eliminating the negative myths that they don't have contribution to employment in public spot advertisements.
\end{abstract}

Keywords: Disabled, employment, disability employment, public spot, advertising

Önerilen atıf şekli: Gazi, M. A., Çakı, C. (2019). Engelli İstihdamına Yönelik Hazırlanan Kamu Spotu Reklamları: Amerika Birleşik Devletleri Çalışma Bakanlığı Üzerine İnceleme. Sosyal Güvenlik Dergisi (Journal of Social Security). 9(2). 409-430.

Geliş Tarihi/Received: 18/02/2019 • Güncelleme Tarihi/Revised: 02/08/2019 • Kabul Tarihi/Accepted: 16/12/2019

\footnotetext{
* Arş. Gör.Dr., Trabzon Üniversitesi, İletişim Fakültesi, mehmetaligazi@hotmail.com

** Arş. Gör., İnönü Üniversitesi, İletişim Fakültesi, caner.caki@inonu.edu.tr
} 


\section{GíRiş}

Engelli istihdamını teşvik etmek amacıyla dünya genelinde pek çok ülkede yasal düzenlemeler yapılmaktadır. Bu ülkelerin başında da Amerika Birleşik Devletleri gelmektedir. ABD Çalışma Bakanlı̆̆g'nın 2017 yılı verilerine göre, ülkedeki engelli nüfusun yalnızca \%18,7'sinin istihdam edildiği sonucuna ulaşılmıştır (DOL, 2019a). Elde edilen düşük oranlar, engelli istihdamının yalnızca kanunlar yoluyla teşvik edilmesinin yeterli olmadığı sonucunu beraberinde getirmektedir. Bu amaçla Çalışma Bakanlığ ülke genelinde engelli bireylerin çalışma isteklerini arttırmak ve işverenleri engelli bireyleri çalıştırma yönünde motive etmek için geniş bütçeli reklam kampanyalarına yönelmektedir. $\mathrm{Bu}$ kampanyalar arasında en dikkat çeken, "What can you do?/Ne yapabilirsin?" adlı kamu spotudur. Reklam kampanyası kampsamında hazırlanan kamu spotlarında doğrudan istihdam içerisinde yer alan engelli bireylere yer verilerek, kamuoyunda engelli istihdamına yönelik farkındalık oluşturulması planlanmıştır. Bu çalışma kapsamında "Ne yapabilirsin?" adlı reklam kampanyası özelinde, engelli istihdamını teşvik etmek amacıyla hazırlanan kamu spotu reklamlarında verilmek istenen açık ve gizli mesajların ortaya konulması amaçlanmaktadır.

Türkiye'de son yıllarda engelli istihdamı üzerine literatürde önemli akademik çalışmaların yapıldığı gözlemlenmiştir. Bunlar içerisinde; Genç ve Çat (2013), "Engellilerin İstihdamı ve Sosyal İçerme İlişkisi" adlı çalışmada, engellilerin istihdama teşvik edilmesinde mesleki rehabilitasyon merkezlerinin rolünü ortaya koymaktadır. Çalışma sonucunda, mesleki rehabilistasyon merkezlerinin, engelli bireyleri çalışma ortamına çekerek üretim faaliyetlerinde yer almalarını teşvik ettiği ve bu yolla gerek sosyal gerekse ekonomik olarak bulundukları topluma katma değer sağlamalarına yardımcı olduğu saptanmıştır. Aynı çalışmada üretime katılan engelliler üzerinde piskolojik iyileşme sağlandığı yönünde tespitler yapılmaktadır.

Köksal (2010), "Türkiye'de Engelli İstihdamı ve Bir Araştırma" adlı çalışmada engelli bireylerin istihdamları üzerine incelemede bulunmuştur. Yüz yüze görüşme tekniği kullanılarak yapılan bu çalışmada, istihdam edilen engellilerin düşük ücrette çalıştığı, ileri düzeyde özrü olan engelli bireylerin çalışma hayatında sınırlı olarak yer aldığı ve engellilerin genel olarak az vasıf gerektiren basit işlerde çalıştırıldığı sonuçlarına ulaşılmıştır.

Çavuş ve Tekin (2015), "Türkiye'de Engellilerin İstihdam Yöntemi Olarak Korumalı İşyeri" adlı çalışmada engellilerin hem çalışma hayatına teşvik edilmesinde hem de rehabilitasyonlarında önemli bir rol oynayan korumalı iş yerleri üzerine incelemede bulunmuştur. Çalışma sonucunda, korumalı işyerlerinin engellilerin istihdamında önemli olduğu, korumalı işyerlerinde engellilerin istihdamının ön plana çıkarılmasının istenilen düzeyde verim alınmasını önlediği ortaya konulmuştur.

Zaim Gökbay vd. (2012) "Engelli Bireylerin İstihdamına Yönelik Bir Vaka Çalışması: Engelsiz Eğitim" adlı çalışmada engelli ihtiyaç, istek ve yetkinliklerini ön planda tutan ve eğitmenleri akademisyenlerden oluşan bir programın önemini vurgulamaktadır.

Göstergebilimsel analiz yöntemi kullanılarak ayrımcılık, güvenlik, çalışma vb. konular üzerinde kamu spotu reklamlarını inceleyen son dönemde önemli akademik çalışmaların yapıldığı görülmektedir. Arpa ve Çakı (2018), Avustralya ve Singapur iş güvenliği reklamlarını konu aldığı çalışmada, kamu spotu reklamlarında; çalışanlara iş güvenliğinin önemini vurgulama amacıyla hangi duygusal çekiciliklerin kullanıldı̆̆ını ortaya koymaya çalışmıştır. Arpa (2018) kamu spotu reklamlarında iş güvenliğinin öneminin vurgulanmasında, korku çekiciliğinin nasıl ve ne yönde kullanıldığını incelemiştir. 
Çalışmada, kamu spotu reklamlarında iş güvenliğine riayet edilmediği takdirde çalışanların başlarına gelebilecek iş kazaları gösterilerek kitlelerin istenilen yönde ikna edilmesinin amaçlandığ1 tespit edilmiştir. Çakı ve Gülada (2018) Müslüman göçmenlere yönelik yapılan ayrımcılıklara karşı hazırlanan kamu spotu reklamlarını analiz etmiştir. Çalışmada, kamu spotu reklamları üzerinden Müslüman göçmenlerin bulundukları toplumun bir parçası oldukları ve ekonomik hayata önemli katkılar sağladıkları vurgulanarak, Müslüman göçmenlere karşı ayrımcılığın ortadan kaldırılmasının amaçlandığı sonucuna ulaşılmıştır.

Türkiye'de engelli istihdamı üzerine yapılan akademik çalışmalar kapsamlı bir şekilde incelendiğinde, engellilerin çalışma hayatına teşvik edilmesi sürecinde hazırlanan kamu spotu reklamları üzerine herhangi bir akademik çalışmanın yapılmadığı ortaya çıkmaktadır. $\mathrm{Bu}$ açıdan ulusal çalışmalar içerisinde değerlendirildiğinde, incelenen konu özgün olması bakımından önem taşımaktadır.

\section{I- ENGELLİ İSTIHDAMI}

Dünyamız sürekli bir değişim ve gelişim kaydetmektedir. Bu değişim ve gelişim insanların yaşamlarıyla birlikte yaşam biçimlerini de değiştirmektedir. İnsanoğlu doğumu ve doğumundan itibaren yaşam içerisinde bedensel veya zihinsel farklılıklar ve eksikliklere sahip olabilir. Bu eksiklikler ve farklılıklardan dolayı birey, toplumda ötekileştirilmektedir. (Csikszentmihalyi ve Csikszentmihalyi, 1975:45-75). Tarihsel süreçlerde ötekileştirmeye neden olan engellilik, sadece tıbbi bir sorunmuş gibi algılanmış ve sosyal yönüyle ilgilenilmemiştir. Engellilere yönelik acıma, yardım etme gibi unsurların altında yatan temel sebep ise dini nedenlere dayandırılmıştır. Modern toplumlar, engelliliği tıbbi bir sorun olarak değil toplumsal bir sorun olarak algılanmalarının ardından ötekileştirmeye neden olan özürlü, sakat, eksik, yoksun gibi kavramların yerine engelli kavramı kullanılmaya başlanmıştır.

Çağdaş sosyal devlet düşüncesi ve oluşumu içinde devletin rolü derin bir biçimde değişmektedir. Devletin rolü, savaşma veya koruma algısının dışında toplumsal refahı düzenlemek ve yaymak olarak tanımlanmaktadır. Devletler, toplumsal refahı toplum içerisindeki bireysel farklılıklar doğrultusunda yasal düzenlemeler yaparak sağlamaktadır. Toplumda farklılıklarıyla ön plana çıkan birincil grup engelli bireylerdir. Kişinin, bedensel, ruhsal ve duyusal işlevlerinin bir kısmı ve tamamı devamlı olarak işlevsel olmaması ve bunun normal yaşamın gereklerine uymaması durumuna engellilik denilmektedir (Fidan ve Yeşil, 2018:1). 5378 sayılı Engelliler Hakkındaki Kanun'un 3. maddesinde ise engellilik kavramını "Fiziksel, zihinsel, ruhsal ve duyusal yetilerinde çeşitli düzeyde kayıp bulunan ve bundan dolay toplum içerisinde diğer üyeler ile eşit koşullarda görülmeyen, toplumsal hayata tam ve etkin katılım sağlayamayan ayrıca birtakım tutumsal ve çevresel koşullarından etkilenen birey" olarak tanımlamaktadır. Bu ifadelerden yola çıkarak engellilik halinin bireyi diğer bireylerden farklılaştırdığı, toplumsal hayata katılımı veya uyumu güçleştirdiği söylenebilmektedir. $\mathrm{Bu}$ durum üzerinde de tutumsal, çevresel vs. birtakım faktörler etkili olmaktadır (Hüseyinli vd., 2017: 139).

Türk Dil Kurumu (TDK) sözlügüüne göre engel, bir şeyin gerçekleşmesini önleyen sebep, mâni, mahzur, müşkül, pürüz, mânia, handikap, ket olarak tanımlanmaktadır. Engelli ise “vücudunda eksik veya kusuru olan, özürlü” olarak açıklanmaktadır (TDK, 2019). Engellilik, toplum yaşamında, kişinin başkaları ile eşit düzeyde yer alma fırsatlarını yitirmesi ya da sınırlandırılması anlamına gelmektedir (Odabaş ve Güneş, 2017: 31). Engelli bireyler, okul sistemine dâhil olma, istihdam edilme, toplumda bağımsız yaşama, özgürce hareket etme, oy kullanma, spor ve kültürel etkinliklere katılma, tıbbi tedavi seçimi ve mülk alıp satmak ve diğer insanlar gibi eşit şekilde topluma katılmalarını engelleyen ayrımcılık ve problemlerle karşılaşmaktadır (Bound ve Timothy, 2002: 37). İnsan Hakları 
Evrensel Bildirgesi’nin 23. maddesinde “Herkesin, hiçbir fark gözetilmeksizin, eşit iş karşıllı̆̆ında eşit ücrete hakkı vardır" ifadesi yer bulmaktadır. Bu bildirgede belirtildiği gibi kişiler arasında fark gözetilmemelidir. Engellilerin kamu ya da özel kuruluşlar da iş yeri çalışma koşulları, saati ve süresine, kariyer gelişimi ve güvenliğine ilişkin hiçbir hususta engelliliğe dayalı negatif ayrımcılık yapılmamalıdır. Anayasal düzen engellilere yönelik ayrımcılığı engelleyen nitelikli önlemler almakla yükümlüdür (Talas, 2015: 409).

Engelli bireylere, insan hakları sözleşmeleriyle garanti edilen çalışma hakkı, anayasal zorunluluk veya cezai müeyyidelerle düzenlenmesine rağmen engelli istihdam oranları düşük kalmaktadır. Engelli bireylerin istihdamını artırmaya yönelik dünyada en yaygın kullanılan sistem kota sistemidir. Kota sistemi, iş yerlerinin çalışan sayısının belli oranında engelli bireyleri çalıştırma zorunluluğudur. Bu uygulamayı ilk defa 1919 yılında Almanya kullanmıştır. Almanya'nın ardından 1920'de Avusturya, 1921'de İtalya, Polonya, 1923 yılında Fransa kota sistemiyle belli oranda engelli istihdam edilmesini zorunlu kılmıştır (Seyyar, 2000: 75). Türkiye'de ise 4857 sayılı İş Kanunu'nun 30. maddesi kapsamında; "İşverenler, elli veya daha fazla işçi çalıştırdıkları özel sektör işyerlerinde yüzde üç engelli; kamu işyerlerinde ise yüzde dört engelli bireyi meslek, beden ve ruhi durumlarına uygun işlerde çalıştırmakla yükümlüdürler" yer alan ifadeyle birlikte işyerlerinde ve kamu alanında engelli çalışma oranları yasayla düzenlenmiştir.

Araştırmacılara göre engellilerin düşük istihdam oranlarının olası nedenleri arasında beceri faktörlerinin yanında, engellilerin eğitim düzeyleri de önemli rol oynamaktadır (Aakvik, 2003: 22; Burchardt, 2005: 86). Eğitimli engellilerin, diğer engellilere oranla iş istihdam oranları daha yüksek olmakta ve daha kolay işlerde çalışabilmektedir. Dünyada, 18-55 yaş arası engelli bireylerin sadece \% 34,5 engelli bir bireye uygun işte çalışmaktadır (EYH, 2019). Engelli bireyler arasında işsizlik oranı diğer işsizlik rakamlarına göre üç kat daha fazla olmaktadır. Türkiye'de ise son yıllarda desteklenen engellilere yönelik politikalar ve çalışmalar, engellilerin istihdam oranlarında önemli artışlar sağlamıştır.

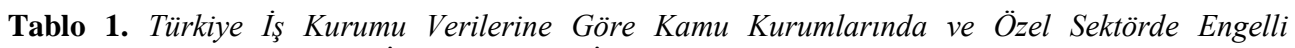
Kotasında Başvuru Yapan ve İstihdam Edilen İsçilerin Yıllara Göre Dă̆ıllımı

\begin{tabular}{ccccc}
\hline Yıllar & Başvuru & \multicolumn{3}{c}{ Isșe Yerleştirme } \\
\hline $\mathbf{2 0 1 8}$ (Mart) & 31.380 & Kamu & Özel & Toplam \\
\hline $\mathbf{2 0 1 7}$ & 100.201 & 192 & 3.861 & 3.890 \\
\hline $\mathbf{2 0 1 6}$ & 79.321 & 236 & 11.959 & 12.151 \\
\hline $\mathbf{2 0 1 5}$ & 65.255 & 258 & 20.197 & 15.031 \\
\hline $\mathbf{2 0 1 4}$ & 77.632 & 232 & 26.118 & 20.455 \\
\hline $\mathbf{2 0 1 3}$ & 76.235 & 287 & 34.189 & 26.350 \\
\hline $\mathbf{2 0 1 2}$ & 83.955 & 398 & 35.133 & 34.476 \\
\hline $\mathbf{2 0 1 1}$ & 35.151 & 455 & 37.894 & 35.531 \\
\hline $\mathbf{2 0 1 0}$ & 36.144 & 295 & 31.962 & 32.349 \\
\hline $\mathbf{2 0 0 9}$ & 40.519 & 545 & 25.860 & 26.405 \\
\hline $\mathbf{2 0 0 8}$ & 48.480 & 427 & 21.540 & 21.967 \\
\hline
\end{tabular}

(Kaynak: İŞKUR, 2018) 
İstihdam verilerine göre yıllar içerisinde engelli bireylerin, çalışma hayatına katılma arzusu artmaktadır. Fakat engelli istihdam oranları, iş başvuru oranlarına göre ortalama \%10-15 arasında kalmaktadır. İstihdam oranlarının düşük kalmasındaki unsurlardan biri, işverenler tarafından engelli bireyleri çalıştırmanın diğer çalışanlara göre daha maliyetli olduğunun düşünülmesidir (Bara, 2013: 134). Türkiye'de engelli çalıştırmaya yönelik primlerin devlet tarafından karşılanması ${ }^{1}$ diğer çalışanlara göre maliyetleri düşürmektedir. Ayrıca işverenlere göre, engelli çalışanların işyerinde aktif olmadıkları ve iyi performans göstermediklerinde, engellilerin şirket performansının ve kârın azaldığı ifade edilebilmektedir. Buna karşın Rutgers Üniversitesi'nden John J. Heldrich İşgücü Geliştirme Merkezi'nin yaptığı araştırmaya göre, engelli bireylerin iş performansının, işe devamlılık oranının ve müşteri ile olan ilişkilerinin diğer çalışanlara oranla daha yüksek olduğu ortaya konulmuştur.

Engelli istihdamı yalnızca ekonomik kaynakları arttırmak için değil, engellilerin sosyal ve psikolojik etkileri için de önemli olmaktadır. Çünkü engellilerin sosyal ilişkilerini, bağımsızlıklarını, etkinlik duygularını arttırmak topluma daha kolay dâhil edilmesinde yardımcı olmaktadır (Schur, 2002: 125). İş gücüne katılamayan engellilerde ise depresyon ve anksiyete bozukluğunun daha yüksek olduğu, öz saygı ve yaşam kalitesinin daha düşük olduğu görülmektedir (Dooley, 1996: 125).

\section{II- KAMU SPOTU REKLAMLARI}

Toplum mühendisleri, bireylere aynı türden bir felsefi, siyasi, ahlaki ve ekonomik bakış açısı kazandırmayı amaçlamaktadır. Bunun toplumların devamlılığı ve toplumsal düzen adına yapıldığını, insanlar tarafından bu kurallar ve düzenlere uyulması durumunda, modern toplumlarda iddia edilen düzenin ve mutluluğun geleceği ifade edilmektedir. Varlığını sürdürmek isteyen tüm iktidar veya yapılar, toplumsal farklılıklar sonucu ortaya çıkabilecek tüm çatışmaları azaltma kaygısı içerisindedir. Bu çatışmaları engellemek ve kaygıları azaltmak için kullanılan yöntemlerden biri, kitle iletişim araçları üzerinden bilgilendirici, eğitici ve yönlendirici yayınlar yapmaktır.

Lee ve Kotler reklamın kural ve ilkeleriyle yapılmış, toplumsal problemleri konu alan, bir düşünceyi ya da tutumu değiştirme amacı taşıyan yayınları "sosyal içerikli reklam” olarak tanımlamaktadır (2011: 45). Sosyal pazarlama veya sosyal reklam kampanyası olarak bilinen kamu spotu, kitle iletişim araçları üzerinden, kamu yararı esasına göre hazırlanmış görüntülü, sesli veya yazılı bilgilendirici mesajları ifade etmektedir (Gazi ve Çakı, 2018: 52). Televizyon ve radyo yayınlarını, toplumsal kurallar ve anayasaya uygunluğunu denetleyen RTÜK’e göre kamu spotu, “...kamu kurum ve kuruluşları ile dernek ve vakıf gibi sivil toplum kuruluşlarınca hazırlanan veya hazırlatılan ve Üst Kurul tarafindan yayınlanmasında kamu yararı olduğuna karar verilen bilgilendirici ve eğitici nitelikteki film ve sesler ile alt bantlardır" (RTÜK, 2019).

Sosyal devlet anlayışının gerekliliği adına kamu spotu reklamlarında kitlelerin pasif durumdan çıkarılarak, toplumsal problemlere yönelik sorumluluk alan bilinçli ve aktif bireylere dönüşümünü gerçekleştirme adına, yazılı veya görsel medya aracılığıyla eğitim, sağlı, çevre ve kadın, çocuk, hayvan hakları gibi konular işlenmektedir (Aytekin, 2016: 250). Klasik reklam argümanının aksine, kamu spotları ile fikri, ticari ve sınai bir ürün ve hizmetin tanıtımı yapılamamakta, kar elde etme amacı güdülmemektedir. Diğer bir deyişle kamu spotu, bireylerin ve toplumların fayda sağlaması amacı ile hazırlanan, izler kitle

\footnotetext{
${ }^{1} 4857$ sayılı İş Kanunu'nun 30. maddesi, 2008/77 sayılı Genelge. Özel sektöre ait işyerlerinde çalıştırılan engelli sigortalıların, prime esas kazanç alt sınırı üzerinden hesaplanan sigorta primi işveren hisselerinin tamamının hazinece karşılanması sağlanmıştır.
} 
üzerinde tutum, davranış, alışkanlık ve bilinç kazandırmayı hedefleyen, yönlendirme unsurunu barındıran sosyal içerikli metinleri ifade etmektedir (Akova, 2017: 18).

Kamu spotlarının ortak özelliği, hedef aldığı kişileri kitlesel olarak eğitmeleridir. Hedef kitlenin inançları, bilgisi, yetenekleri gibi kişisel özellikleri dışına çıkarak sosyal normlar üzerinden bireyleri etkilemeye çalışmaktadır (Çakar, 2017: 235). Kamu spotları, sürekli tekrar ve etkileyici söylemler ile olay örgüsünü gerçekleştirmektedir. Kamu spotlarının, halkı ilgilendiren ve iletilmesinde kamu menfaati dikkate alınan mesajlar bulunmaktadır. Kamu spotunun oluşturulmasında destek veren gerçek ya da tüzel kişilerin adı, firması, firmasını çağrıştıracak herhangi bir materyali, ürettiği ürünleri ya da firma bilgileri veya pazara arz ettiği ürünlerini tanıttığı tespit edilen kamu spotu onay alamamakta ve kitle iletişim araçlarında yayınlanamamaktadır (Şen, 2018: 8).

Bayraktaroğlu ve İlter'e göre kamu spotlarında verilen bilgiler toplumun ekonomik, siyasal ve kültürel yapısına göre bireylerin davranış biçimlerini değiştirmekte ve bu değişimin zorluğu toplumlara göre farklılaşmaktadır (2007: 118). Toplumsal yapılara göre kamu spotu niteliksel ve niceliksel olarak değişebilmektedir. Avrupa'da kamu spotlarında, Göç, AIDS ve Afrika ülkelerine yardım gibi konular yer almaktadır. Gelişmekte olan veya geri kalmış ülkeler de ise kamu spotu genel olarak, temel ihtiyaçların kullanımından, kadın ve çocuk hakları, ilaç kullanımı, trafik kurallarına uyma gibi toplumsal düzeni ve bilişsel gelişimi sağlamaya yönelik bilgilendirici mesajlara yer vermektedir (Gazi ve Çakı, 2018: 53).

Bireylerin davranışlarında olumlu yönde değişiklik yapmak amacıyla pek çok farklı toplumsal konuyu içeren kamu spotu yayınlanmaktadır. Özelikle ülkemizde sağlık alanında kamu spotu reklamları ön plana çıkmaktadır. Bunlar içerisinde Aile Hekimliği, Akılcı Antibiyotik Kullanımı, e-Nabız, Sevgili Geleceğim, Pasif İçicilik-Duman, Să̆lıkta Şiddet ve Haydi Harekete Geç gibi kamu spotu yayınları bulunmaktadır. Bu kamu spotu reklamları devlet kurumları tarafından yapılmış ve yayınlanmıştır. Ülkemizde, ekonomik ve sosyal politikaların doğal bir sonucu olarak, engelli çalışmalarıyla ilgili önemli güncellemeler de yapılmaktadır.

\section{III- GÖSTERGELER MODELI}

Göstergebilim, göstergeleri inceleyen ve 20. yüzyılın başında ortaya çıkan bir bilim dalıdır (Sığırcı, 2016: 47). Gösterge ise soyut kavramların somutlaştırılarak insan zihninde bir imaj oluşturmasını ifade etmektedir. Diğer bir tanımla gösterge kendisi dışında bir kavramı temsil eden ve temsil ettiği kavramın yerini tutabilen olgu, biçim, nesne vb. olarak tanımlanmaktadır (Rifat, 2017: 97). Göstergebilimde temel amaç göstergenin herkes tarafından kabul edilen açık ve anlaşılır anlamının dışında; gizli, kültüre özgü ve insanlar tarafından ilk etapta anlaşılamayan anlamını ortaya çıkarmaktır. Göstergebilimde, göstergenin ortaya koyduğu anlam okuyucu denilen, iletişimdeki alıcı pozisyonundaki kişi tarafından çözümlenmektedir (Tekinalp ve Uzun, 2013: 142). Göstergebilimin gelişmesinde 20. yüzyılın başlarında İsviçreli dilbilimci Ferdinand de Saussure ve ABD'li dilbilimci Charles Sanders Peirce'in dilbilimi alanında birbirlerinden habersiz olarak yaptıkları çalışmalar büyük rol oynamıştır. Özellikle Saussure'ün ölümünden sonra öğrencileri tarafından ders notlarından derlenerek oluşturulan ve Genel Dilbilim Dersleri adıyla yayınlanan kitap, Saussure'ün göstergebilim anlayışının uluslararası düzeyde geniş bir tanınırlık elde etmesini sağlamıştır (Kalkan Kocabay, 2008: 14). Saussure'ün göstergebilim analında ortaya koyduğu kavramlar, göstergebilim ortaya çıkmasını ve sosyal bilimler alanında günümüzde de kullanılan Göstergeler Modeli'nin oluşmasını sağlamıştır. 
Göstergeler Modeli'nde, göstergenin gösteren ve gösterilen olmak üzere iki temelde şekillendiği aktarılmaktadır (Fiske, 2017: 127). Gösteren, göstergenin herkes tarafından kabul edilen, değişmeyen, farklılık oluşturmayan, evrensel anlamını ifade etmektedir. Saussure'e göre göstergenin gösteren açısından anlamında genel bir uzlaşı söz konusudur. $\mathrm{Bu}$ açıdan bir göstergenin, gösteren açıdan anlamının değişmesi çok güç olarak değerlendirilmektedir. Gösterilen ise göstergenin tamamen zıttı bir kavramı ifade etmektedir. Gösterilen, göstergenin kültüre özgü, farklılaşabilen, evrensel anlamlandırmaları içermeyen ve zaman içerisinde değişebilen anlamını açıklamaktadır. Gösterilen açıdan bir göstergenin anlamının yorumlanabilmesi için o göstergeyi kullanan kültürün iyi tanınması gerekmektedir. Çünkü göstergenin anlamlandırması kültürden kültüre farklılaşabilmektedir (De Saussure, 2014: 63). Örneğin, sıradan bir terazi gösteren açıdan bir ölçü birimini ifade etmektedir. Buna karşın, gösterilen boyutta ise terazi, adalet kavramının bir temsili olarak anlamlandırılabilmektedir. Saussure, göstergelerin anlamlandırılması sürecinde toplumda genel bir uzlaşının olması gerektiğini savunmaktadır. Diğer bir değişle bir göstergenin anlamlandırılabilmesi için göstergenin temel özellikleriyle olan benzeşmesinden ziyade, gösterge ve kavram arasında toplumun ortak bir kararda birleşmesi önemli olmaktadır (Güngör, 2013: 214). Bu açıdan göstergenin anlamlandırılmasında toplumun ortak kararları ön plana çıkmaktadır. Saussure'ün göstergebilim alanındaki çalışmaları pek çok çağdaşını etkisi altında bırakmış ve ortaya koyduğu kavramlar ile yeni modellerin oluşmasını sağlamıştır.

\section{IV- YÖNTEM}

\section{A- Çalışmanın Amacı}

Çalışma kapsamında ABD Çalışma Bakanlı̆̆ı'nın desteğiyle hazırlanan "Ne Yapabilirsin?" adlı reklam kampanyası üzerinden engelli istihdamını arttırmaya yönelik hazırlanan kamu spotu reklamlarında engelli bireylerin nasıl ve ne şekilde sunuldukları ortaya konulmaya çalışılmıştır. Bu şekilde çalışma özelinde engelli istihdamını arttırmada kamu spotu reklamlarının rolü açıklanmaya çalışılmıştır.

\section{B- Çalışmanın Önemi}

Türkiye'de engelli istihdamına yönelik yapılan akademik çalışmaların oldukça sınırlı olduğu görülmektedir. Diğer yandan engelli bireylerin çalışma hayatına teşvik edilmesine yönelik hazırlanan reklam kampanyaları üzerine incelemede bulunan ulusal alanda herhangi bir akademik çalışmaya da rastlanılmamaktadır. Bu açıdan çalı̧̧ma engelli istihdamının teşvik edilmesinde reklam kampanyalarının ne gibi bir rol oynadığını ortaya koyması bakımından önem taşımaktadır. Diğer taraftan, çalışma ileride Türkiye'de engelli istihdamını arttırmaya yönelik hazırlanacak kamu spotlarının içeriğinin belirlenmesinde önemli bir kaynak oluşturabilmektedir. Çalışma ABD özelinde yapılması bakımından doğrudan $\mathrm{ABD}$ boyutunda engelli istihdamını konu almaktadır. Bu açıdan Türkiye'de yapılacak engelli istihdamını konu alan kamu spotu reklamlarının kültürel kodları dikkate alarak Türkiye özelinde hazırlanması uygun olacaktır.

\section{C- Çalışmanın Evreni ve Örneklemi}

Çalışmanın evreni dünya genelinde engelli istihdamını konu alan tüm kamu spotu reklamlarını kapsamaktadır. Buna karşın engelli istihdamını konu alan tüm kamu spotu reklamlarına ulaşmanın güçlüğünden dolayı çalışmada örneklem kullanılmıştır. Bu amaçla çalışmada ABD Çalışma Bakanlığı'nın desteğiyle başlatılan CSE kısaltması altında "What 
can you do?/Ne yapabilirsin?" adlı engelli istihdamına yönelik reklam kampanyası çalışmanın örneklemi olarak belirlenmiştir. Son yıllarda engelli istihdamında ulusal ve uluslararası basında farkındalık oluşturması, diğer yandan uzun soluklu ve süreklilik arz etmesi gibi nedenlerden dolayı CSE çalışmanın örneklemi olarak belirlenmiştir.

\section{D- Çalışmanın Sınırııııkları}

Çalışmada yalnızca ABD Çalışma Bakanlığı destekli CSE reklam kampanyasındaki kamu spotu reklamlarının incelenmesi ve elde edilen bulgular kapsamında kamu spotu reklamlarının engelli istihdamını teşvik etmedeki rolü ile ilgili genellemelerde bulunulması çalışmanın temel sınırlılığını oluşturmaktadır.

\section{E- Çalışmanın Soruları}

Çalışma kapsamında aşağıdaki sorulara yanıt aranmaya çalışılmıştır;

CSE'nin engelli istihdamını konu alan kamu spotu reklamlarında:

- Hangi konular ön plana çıkarılmıştır?

- $\quad$ Engellilere yönelik hangi açık ve gizli mesajlar verilmektedir?

- Engellilere yönelik hangi olumsuz algıların ortadan kaldırılması amaçlanmıştır?

\section{F- Çalışmanın Yöntemi}

Çalışmada nitel araştırma yöntemleri içerisinde yer alan göstergebilimsel analiz yöntemi kullanılmıştır. Çalışma kapsamında belirlenen kamu spotu reklamları ise Saussure'ün Göstergeler Modeli üzerinden analiz edilmiştir.

\section{V- ANALIZ}

Çalışmanın bu bölümünde "Kimim", "Yapabilirim", "İşler" başlıklı reklam kampanyaları incelenmiştir.

\section{A- "Kimim" Başılıklı Reklam Kampanyası}

"Kimim" başlıklı reklam kampanyasında "Gazi", "Büro Memuru" ve "Öğretmen" konulu kamu spotu reklamları analiz edilmiştir.

\section{i) "Gazi" Konulu Kamu Spotu Reklamı}

"Gazi" konulu kamu spotu reklamında yer alan Ron Drach ile ilgili şu bilgiye yer verilmektedir; "Ron Drach, gazi meselelerine, özellikle de yaralı askerlere odaklanan serbest çalışan bir danışmandır. Bu görevde, gazi odaklı girişimler konusunda sayısız kuruluşa danışmanlık hizmeti vermektedir. Ron, Vietnam Savaşı'nda sağ ayağını kaybetti ve protez bir ayak kullanmaktadır. Ron, birkaç yıl önce ABD Çalışma Bakanlığı'ndan emekli olduktan sonra danışmanlık işine başladı. Ondan önce, yine gazilik ile ilgili birimler için çalıştı." Kamu spotu reklamı gösteren açıdan incelendiğinde, posterde mavi bir arka fon üzerinde protez bir bacak kullanan yaşlı bir erkek fotoğrafına yer verildiği görülmektedir. Görsel kodlar içerisinde erkeğin protez bacağını gösterdiği ve gülümsediği yansıtılmaktadır. Posterin sağ yanında "Ron Drach, büyükbaba, gazi, küçük işletme sahibi, protez bacak" ve sol yanında ise "Yeteneklerimi ve özelliklerimi kullanacağım bir şansa sahibim" yazılı kodları bulunmaktadır. 
Engelli İstihdamına Yönelik Hazırlanan Kamu Spotu Reklamları: Amerika Birleşik Devletleri Çalışma Bakanlığı Üzerine İnceleme

Tablo 2. Göstergeler Modeli Băglamında "Gazi" Konulu Kamu Spotu Reklamı

\begin{tabular}{ccc}
\hline Gösterge & Gösteren & Gösterilen \\
\hline İnsan & Savaş gazisi & Engelli bireylerin yetenekleri doğrultusunda çalışabilecekleri \\
\hline Sağlık & $\begin{array}{c}\text { Protez } \\
\text { bacak kullanımı }\end{array}$ & Çalışma hayatı için bir engel olmadığı \\
\hline $\begin{array}{c}\text { Sosyal } \\
\text { Konum }\end{array}$ & $\begin{array}{c}\text { İş sahibi, } \\
\text { büyükbaba }\end{array}$ & Engelli bireyler de diğer insanlar gibi toplumsal ve ekonomik \\
hayatın bir parçası
\end{tabular}

ABD'de gazilerin bir kısmı sivil hayatta çalışmaya devam etmektedir. 2019 yılının Ocak ayı verilerine göre ABD'de gazi işsizlik oranı yalnızca \%3,7 olarak kalmıştır (DOL, 2019b). Gösterilen açıdan incelendiğinde kamu spotu reklamındaki gazinin, yaşadığı engele rağmen ekonomik ve toplumsal hayata katkı sunmaya devam ettiği aktarılmaktadır. Gazi, kampanyada ekonomik hayatta başarı gösteren engelli bireylerin örnek bir temsili olarak sunulmaktadır. Gazinin doğrudan mavi arka fon üzerinden sunulması ile de posterdeki dikkatlerin doğrudan gazinin üzerine odaklanması planlanmaktadır. Görsel kodlar içerisinde gazinin gülümsemesi ile çalışmaktan memnun olduğu izlenimi oluşturulmaktadır. Diğer yandan reklam kampanyasının girişinde gaziye atfen söylenen sözler ile de gazinin çalışmaktan mutlu olduğu algısı güçlendirilmektedir. Gazi üzerinden verilmek istenen genel mesaj, fiziksel engellerin çalışma hayatı için engel teşkil etmediği yönündedir. Bu yolla insanların zihinlerindeki "engelli bireyler çalışamaz" algısının ortadan kaldırılması amaçlanmaktadır. Bu olumsuz algının yerine ise "engelli bireylerin toplumsal ve ekonomik hayatın bir parçası" oldukları mesajının verilmesi istenmektedir.

Resim 1. "Gazi" Konulu Kamu Spotu Reklamı

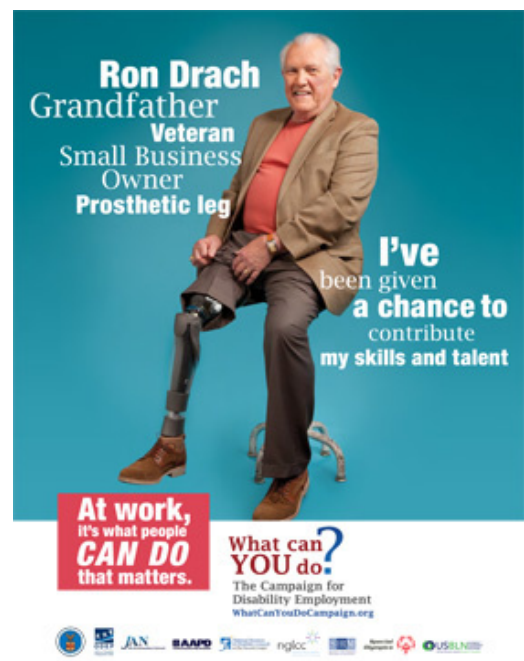

(Kaynak: CDE, 2018)

\section{ii) "Büro Memuru" Konulu Kamu Spotu Reklamı}

"Büro Memuru" konulu kamu spotu reklamında yer alan Vander Cherry ile ilgili şu bilgilere yer verilmektedir; "Vander Cherry, ABD Eğitim Bakanlığı'nda bir büro memurudur ve burada kredi alıcılarıyla yazışmaları işlemeye yardımcı olmaktadır. Hem zihinsel hem de fiziksel engellidir. Çeşitli destekler, iş koçu ve yardımcı teknoloji çalışma 
hayatında kalmasına yardımcı olmaktadır. Vander, 2012 yılında, İstisnai Çocuklar Konseyi'nden 'Evet Yapabilirim!' Ödülüne layık görüldü." Kamu spotu reklamı gösteren açıdan incelendiğinde, posterde mavi bir arka fonun önünde siyahi bir erkek fotoğrafina yer verildiği görülmektedir. Görsel kodlarda erkeğin gülümsediği yansıtılmaktadır. Posterin solunda "Engelim benim kim olduğumun yalnızca bir bölümüdür" ve sağında "Vander Cherry, kahverengi gözlü, büro memuru, zihinsel ve bedensel engelli" yazılı kodu bulunmaktadir.

Tablo 3. Göstergeler Modeli Bağlamında "Büro Memuru" Konulu Kamu Spotu Reklamı

\begin{tabular}{ccc}
\hline Gösterge & Gösteren & Gösterilen \\
\hline İnsan & Büro memuru & İş hayatında engelliler de bulunmaktadır \\
\hline Sağlık & $\begin{array}{c}\text { Bedensel ve zihinsel } \\
\text { engel }\end{array}$ & $\begin{array}{c}\text { Bedensel ve zihinsel engelin çalışma için bir engel } \\
\text { olmadı̆̆1 }\end{array}$ \\
\hline $\begin{array}{c}\text { Diş } \\
\text { Görünüş }\end{array}$ & Kahverengi gözler & Engellilerin yalnızca engeline odaklanılmaması \\
\hline \hline
\end{tabular}

ABD Çalışma Bakanlığı'nın 2016 yılı verilerine göre ülkede iş gücünde bulunan siyahilerin oranı \%12,6'lık bir kısmı oluşturmaktadır. Diğer bir deyişle ABD'de çalışan her sekiz kişiden biri siyahidir (DOL, 2019c). Gösterilen açıdan incelendiğinde, posterde siyahi büro memuru üzerinden bedensel ve fiziksel engellerin çalışmaya engel olmadığ aktarılmaktadır. Diğer yandan posterde engelli bireylerin yalnızca engellerine odaklanılmaması gerektiği mesajı verilmektedir. Posterdeki kişinin kahverengi gözlere sahip olması ve büro memuru olması gibi farklı özellikleri vurgulanarak, bir kişiye yalnızca engelleri üzerinden genellemelerde bulunulmaması gerektiği aktarılmaktadır.

Resim 2. "Büro Memuru" Konulu Kamu Spotu Reklamı

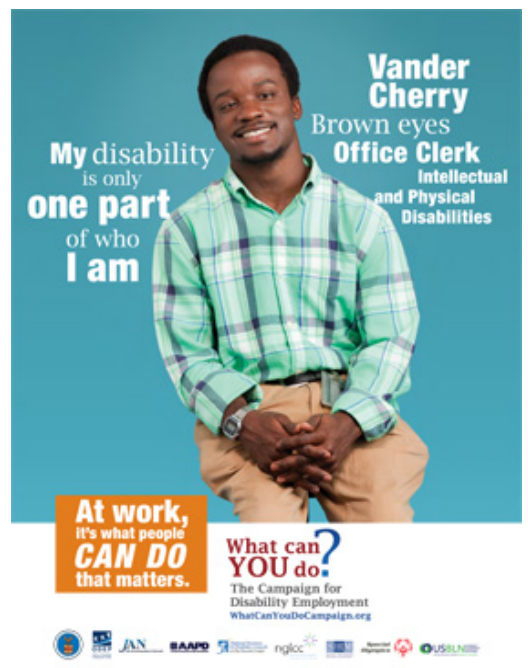

(Kaynak: CDE, 2018)

\section{iii) "Öğretmen" Konulu Kamu Spotu Reklamı}

"Öğretmen" konulu kamu spotu reklamında yer alan Elizabeth Kumar için kampanyada şu bilgilere yer verilmektedir; "Elizabeth Kumar, lupusu (deri veremi) olan ve semptomlarının 
bir sonucu olarak tekerlekli sandalye kullanan bir öğretmendir. Hastalığının teşhisinden önce sınıf öğretmenliği yapmaktaydı. Ancak işe döndükten sonra, daha fazla esnekliğe ihtiyaç duyduğunu hissetti ve özel ders vermeye başladi. Halen Kuzey Virginia'da çalışmaktadır. Ayrıca çevrimiçi olarak da ders vermektedir." Kamu spotu reklamı gösteren açıdan incelendiğinde, posterde tekerlekli sandalye üzerinde bir kadın fotoğrafına yer verilmiştir. Görsel kodlar içerisinde kadının gülümsediği ve eliyle tekerlekli sandalyesini tuttuğu yansitılmaktadır. Posterin solunda "Elizabeth Kumar, eş, öğretmen, velupus" ve sağında "Sevdiğim işte çalışıyorum" yazılı kodu yer almaktadır.

Tablo 4. Göstergeler Modeli Bağlamında "Öğretmen" Konulu Kamu Spotu Reklamı

\begin{tabular}{ccc}
\hline Gösterge & Gösteren & Gösterilen \\
\hline İnsan & Öğretmen & Engelliler de sevdiği işlerde çalışabilmektedir \\
\hline Sosyal Konum & Anne, öğretmen & Engellilerin yalnızca engeline odaklanılmaması \\
\hline Nesne & Tekerlekli sandalye & Çalışma hayatı için bir engel olmadığı \\
\hline \hline
\end{tabular}

Gösterilen açıdan ele alındığında posterde yer alan kadın üzerinden, engellerin çalışma hayatı için bir engel teşkil etmediği mesajının verilmek istendiği görülmektedir. Böylece engelli bireylerin çalışmaya teşvik edilmesi planlanmaktadır. Diğer yandan engelli bireylerin her zaman devlet tarafindan verilen rastgele işlerde değil, sevdikleri işlerde de çalışabilecekleri mesajı verilmektedir. Posterde yer alan kadının hastalığından sonra çalışma şartlarının değiştirilmesiyle yine işini sürdürebildiği mesajı aktarılmaktadır. $\mathrm{Bu}$ açıdan engelli bireyler için uygun bir ortam oluşturulduğunda diğer insanlar gibi çalışmalarının mümkün olabileceği yansıtılmaktadır.

Resim 3. "Öğretmen" Konulu Kamu Spotu Reklamı

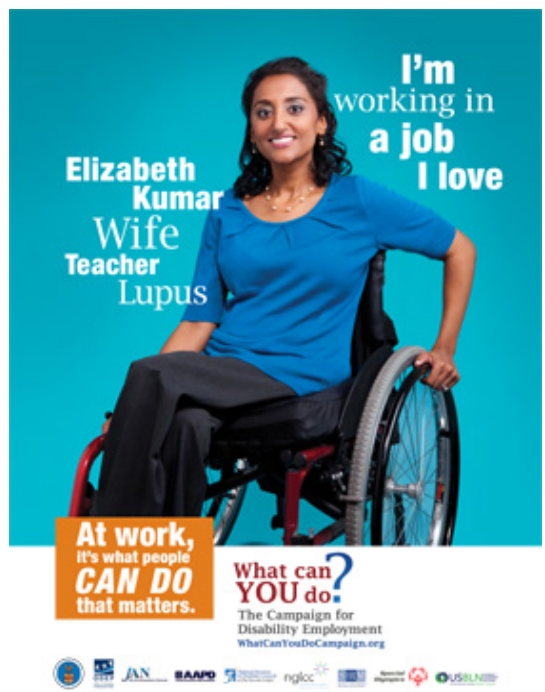

(Kaynak: CDE, 2018)

\section{B- "Yapabilirim" Başlıklı Reklam Kampanyası}

"Yapabilirim" başlıklı reklam kampanyasında "Engelli Nüfus", "Yetenek" ve "Çalışma" konulu kamu spotu reklamları analiz edilmiştir. 


\section{i) "Engelli Nüfus" Konulu Kamu Spotu Reklamı}

"Engelli Nüfus" konulu kamu spotu reklamında yer alan Mat McCollough ile ilgili şu ifadelere yer verilmiştir; "Kolombiya Bölgesi Gelişimsel Engelliler Konseyi icra direktörü ve 'Yapabilirim' adlı kampanyanın yıldızlarından biri olan Mat McCollough ile tanışın. 2011 yılında, Başkan Barack Obama tarafından engellilerin erişimine adanmış bağımsız bir federal ajans olan ABD Erişim Kurulu'nda görev yapmak üzere atandı. Serebralpalsili olan ve yürümesine yardımcı olmak için koltuk değneği kullanan Mat, siyaset bilimi alanında lisans derecesine ve kamu yönetiminde yüksek lisans derecesine sahiptir." Kamu spotu reklamı gösteren açıdan incelendiğinde, posterde çalışma ortamında koltuk değnekli bir erkek fotoğrafina yer verildiği görülmektedir. Görsel kodlar içerisinde erkeğin gülümsediği yansitılmaktadır. Posterin sol üstünde de "Bizim 56 milyonumuzdan fazlası engele sahiptir" yazılı kodu yer almaktadır.

Tablo 5. Göstergeler Modeli Bağlamında "Engelli Nüfus" Konulu Kamu Spotu Reklamı

\begin{tabular}{ccc}
\hline Gösterge & Gösteren & Gösterilen \\
\hline İnsan & Bedensel engelli & Engelliler de yöneticilik yapabilmektedir \\
\hline Miktar & Engelli sayısı & Engellilerin toplumun önemli bir kısmını oluşturduğu \\
\hline Nesne & Koltuk değneği & Çalışma hayatı için bir engel oluşturmamaktadır \\
\hline
\end{tabular}

Gösterilen açıdan değerlendirildiğinde, posterde istatistiki veriler üzerinden ABD'deki engelli nüfus ile ilgili farkındalık oluşturulmasının amaçlandığı görülmektedir. Engelli bireylerin ABD'nin önemli bir bölümünü oluşturdukları belirtilerek, iş yaşamı içinde de önemli bir iş gücünü teşkil ettikleri vurgulanmaktadır. Posterde üst düzey görevde bulunan bir engelli bireye yer verilerek, engelli bireylerin de çalışma hayatında üst düzey görevlerde yer alabilecekleri aktarılmak istenmektedir. Böylece engelli bireylerin engellerini iş hayatına atılmalarını önleyici bir unsur olarak değerlendirmemeleri istenmektedir. Posterde gerçek hayattan verilen bir örnek ile engelli bireylerin çalışma isteklerinin arttırılması hedeflenmektedir.

Resim 4. "Engelli Nüfus" Konulu Kamu Spotu Reklamı

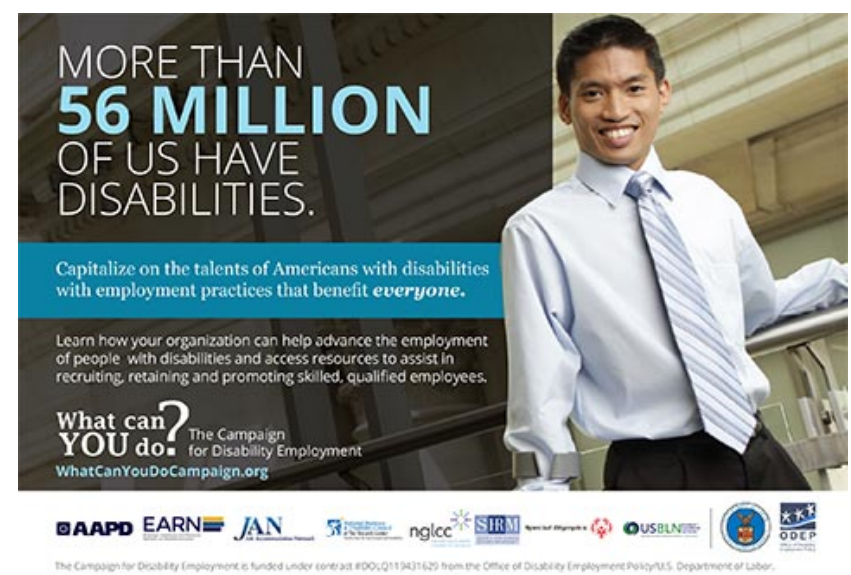

(Kaynak: CDE, 2018) 


\section{ii) "Yetenek" Konulu Kamu Spotu Reklamı}

"Yetenek" konulu kamu spotu reklamında yer alan Cheryl Collier ile ilgili şu bilgilere yer verilmektedir; "Cheryl, işitme engelli bir ilkokul öğretmenidir. Cheryl, Maryland'deki İşitme Engelliler Okulu'nda ders vermekte ve öğrencileri ile iletişim kurmak için işaret dilini kullanmaktadır. Küçük çocuklarla çalışmayı sevdiği için öğretmenliği seçmiştir. Ders vermediği zamanlarda, Cheryl ortaokul ögrencilerine voleybol koçu olarak danışmanlık ve destek sağlamaktadır. "Kamu spotu reklamı gösterilen açıdan incelendiğinde, posterde işaret dili kullanan işitme engelli bir kadın fotoğrafına yer verildiği görülmektedir. Posterdeki görsel kodlarda kadının sınıfta olduğu ve mutlu olduğu yansıtılmaktadır. Posterin solunda "Işste insanların yapabileceği şey bu" yazılı kodu yer almaktadır.

Tablo 6. Göstergeler Modeli Bağlamında "Yetenek" Konulu Kamu Spotu Reklamı

\begin{tabular}{ccc}
\hline Gösterge & Gösteren & Gösterilen \\
\hline İnsan & Öğretmen & Engelliler de toplumsal ve ekonomik hayata katkı sağlamaktadır \\
\hline Sağlık & İşitme engeli & İşitme engeli çalışmaya engel değildir \\
\hline Eylem & İşaret dili & Engellilerin çalışması için bir imkan vardır \\
\hline
\end{tabular}

Gösterilen açıdan değerlendirildiğinde, posterde fiziksel engellerin çalışmaya engel olmayacağı mesajının verildiği görülmektedir. Posterde yer alan işitme engelli kadının işaret dilini kullanarak öğrencileriyle derse devam etmesi, engellerin istenildiğinde aşılabileceği ve iş hayatının sürdürülebileceği mesajını vermektedir. Böylece engelli bireylerin engellerine yönelik ön yargılarını kırmaları ve çalışma hayatına dâhil olmaları istenmektedir. Diğer yandan poster üzerinden engelli bireylerin toplumsal ve ekonomik hayat için önemli bir artı değer olduğu üzerinde durulmaktadır. Bu açıdan engelli bireylerin çalışmasının toplumsal refah için önem taşıdığı aktarılmaktadır.

\section{Resim 5. "Yetenek" Konulu Kamu Spotu Reklamı}

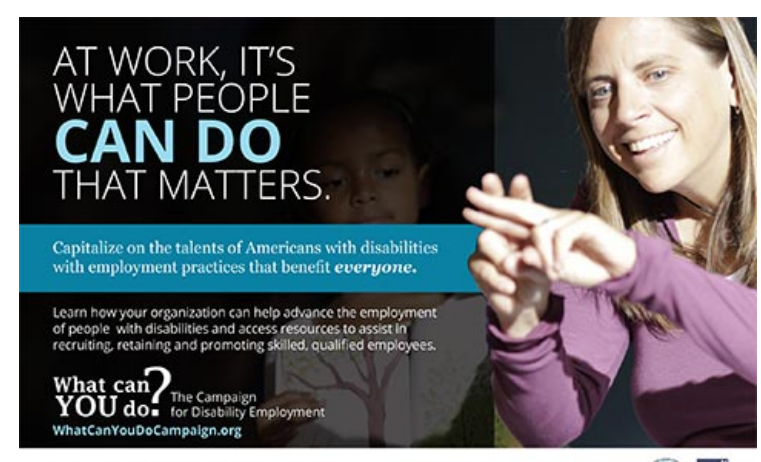

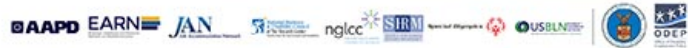

(Kaynak: CDE, 2018)

\section{iii) "Çalışma" Konulu Kamu Spotu Reklamı}

"Çalışma" konulu kamu spotu reklamında yer alan Michael Saulter ile ilgili şu bilgilere yer verilmektedir; "Yapabilirim adlı kampanyanın yıldızlarından biri olan marangoz Michael ile tanışın. Genç olduğundan, her zaman bir şeyler yapmaktan zevk alır. Michael okuma ve yazma becerisini etkileyen zihinsel bir engellidir. Hangi işin sürdürüleceğine karar verirken sakatlığının bir etken olmadığını, ancak müşterilerinin ihtiyaçlarını anladığından emin olmak için farklı yollar geliştirmek zorunda olduğunu söylemektedir. Elleriyle çalışsa da, 
anlama ve iletişim becerilerinin işin önemli bir parçası olduğunu belirtmektedir. "Kamu spotu reklamı gösterilen açından incelendiğinde, posterde siyahi bir erkek fotoğrafına yer verilmektedir. Görsel kodlarda erkeğin gülümsediği yansıtılmaktadır. Posterin solunda ise "Herkes çalıştığı zaman Amerika en iyi çalışmaktadır" yazılı kodu bulunmaktadır.

Tablo 7. Göstergeler Modeli Bağlamında "Çalışma" Konulu Kamu Spotu Reklamı

\begin{tabular}{ccc}
\hline Gösterge & Gösteren & Gösterilen \\
\hline İnsan & Marangoz & Engelliler yardım alarak çalışma hayatına katkı sunabilmektedir \\
\hline Sağlık & Zihinsel engelli & Zihinsel engel çalışmaya engel değildir \\
\hline \multirow{2}{*}{ Eylem } & $\begin{array}{l}\text { Herkesin } \\
\text { çalışması }\end{array}$ & Ülkenin refahı için engellilerin de çalışma hayatına katkı sunması \\
& beklenmektedir
\end{tabular}

Gösterilen açıdan bakıldığında, posterde toplumsal refahın gerçekleşebilmesi için engelli bireylerin da çalışma hayatına katkı sunması istenmektedir. Engelli bireylerin engellerini çalışma hayatından uzaklaşmak için bir neden görmemeleri gerektiği vurgulanmaktadır. Posterde çalışma hayatında başarıya ulaşmış bir engelli bireyin örneği üzerinden engelli bireylerin çalışmasının teşvik edilmesi amaçlanmaktadır. Posterde verilen yazılı kodlarda da engelli bireylerin de ekonomik hayata sundukları katkılar sayesinde ülkenin kalkınmasının gerçekleşebileceği aktarılmaktadır. Bu şekilde engelli bireylerin çalışma hayatına çekilmeleri amaçlanmaktadır.

Resim 6. "Çalışma" Konulu Kamu Spotu Reklamı

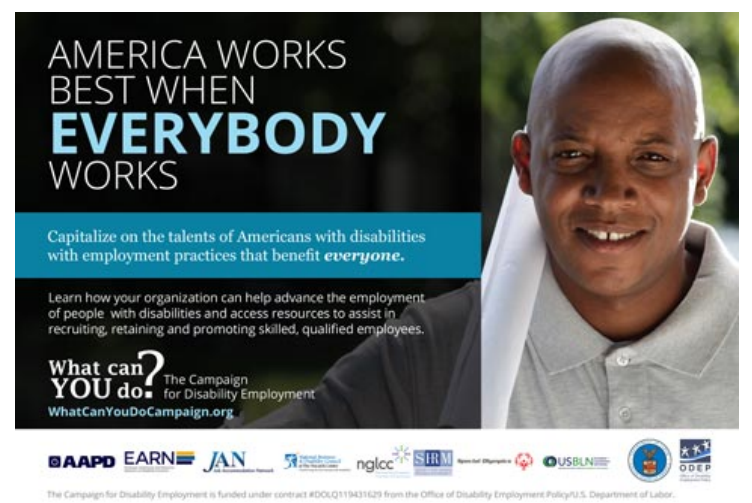

(Kaynak: CDE, 2018)

\section{C- "İşler" Başlıklı Reklam Kampanyası}

"İşler" başlıklı reklam kampanyasında "Araştırmacı", "Marangoz" ve "Gazi" konulu kamu spotu reklamları analiz edilmiştir.

\section{i) "Araştırmacı" Konulu Kamu Spotu Reklamı}

"Araştırmacı" konulu kamu spotu reklamında yer alan Chanelle Houston ile ilgili şu bilgilere yer verilmektedir; "Chanelle Houston, Maryland'de 2008'den bu yana bir halk sağlığı araştırma şirketinde araştırma analisti olarak görev almaktadır. Virginia Beach'te tatildeyken bir araba kazası yaşadı ve kendisini felç bırakan bir omurilik yaralanması yaşadı. Meslektaşlarından ve sağlık ekibinden gelen güçlü destek ile altı aylık rehabilitasyondan sonra işe döndü. Bugün çalışmadığı zamanlarda Chanelle diğer insanları omurilik yaralanmaları ile ilgili yönetmektedir. Ayrıca 2016 Paralimpik yarışmalarında yarışan hevesli bir yüzücüdür. Chanelle, işine tutkulu ve bu tutkunun iyileşmesinde önemli 
bir rol oynadığını belirtmektedir. "Geri dönüp sevdiğim birşeyi yapmak benik için gerçekten motive edici oldu" demektedir." Kamu spotu reklamı gösterilen açıdan incelendiğinde, posterde büro içerisinde bir kadın ve erkeğin fotoğraflarına yer verildiği görülmektedir. Posterde her ikisinin de gülümsediği aktarılmaktadır. Posterin ortasında ise "Hayatımın değiştiği bir anda, işimi sürdürebilmek için bir plan yaptık." yazılı kodu yer almaktadır. Yazılı kodlar kutucuklar içerisinde verildiği için sözlerin fotoğraftaki kadına ait olduğu anlaşılmaktadır.

Tablo 8. Göstergeler Modeli Bağlamında "Araştırmacı" Konulu Kamu Spotu Reklamı

\begin{tabular}{ccc}
\hline Gösterge & Gösteren & Gösterilen \\
\hline İnsan & Araştırmacı & Engelliler de çalışma hayatına katkı sağlamaktadır \\
\hline Sağlık & $\begin{array}{c}\text { Bedensel } \\
\text { engel }\end{array}$ & Bedensel engel çalışmaya engel değildir \\
\hline İnsan & İşveren & Engellilerin çalışma hayatında olmasında işverenler büyük rol \\
oynamaktadır
\end{tabular}

Gösterilen açıdan kamu spotu reklamı incelendiğinde, engelli bireylerin işverenler tarafından desteklenmesinin çalışma hayatında başarılı olmalarında önemli bir rol oynadığ vurgulanmaktadır. İşveren ve engelli bireyin bir arada sunulması ve görsel kodlar içerisinde mutlu aktarılmaları, posterde engelli bireylerin istihdamının arttırılmasında işverenlerin de katkı sağlamaları gerektiğgi algısının oluşmasına yol açmaktadır. Çalışma kapsamında incelenen ilk iki reklam kampanyasından farklı olarak bu reklam kampanyasının ilk kamu spotu reklamında, engelli bireylerden ziyade doğrudan işverenlere odaklanıldığı görülmektedir. $\mathrm{Bu}$ açıdan işverenlerin gerekli sorumlulukları yerine getirerek engelli istihdamında engelli bireylere destek olmaları gerektiği vurgulanmaktadır.

Resim 7. "Araştırmacı" Konulu Kamu Spotu Reklamı

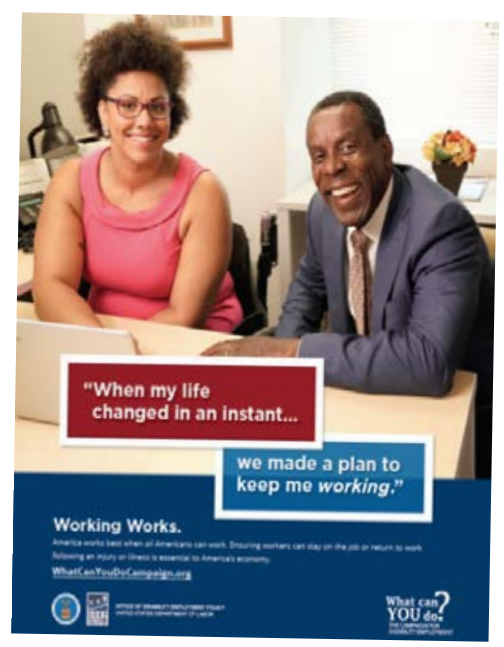

(Kaynak CDE, 2018)

\section{ii) "Marangoz" Konulu Kamu Spotu Reklamı}

"Marangoz" konulu kamu spotu reklamında yer alan Bruce Goebel ile ilgili şu bilgilere yer verilmektedir; "Bruce Goebel, üçüncü nesil bir ahşap işletmesi olan Pennsylvania merkezli Goebelwood Industries'in bir parçasıdır. 2018 yılında dükkanında çalışırken, sağ elini kesen 
bir makine kazası yaşadı. Kaza sonrası çok sayıda ameliyat geçirdi. İyileşmesi sürecinde, ailesi, hekimleri, iş ortakları ve personeli ile birlikte ortak hareket ederek, en kısa sürede çalışmaya kademeli olarak geri dönmeye çalıştı. Bruce haftada üç kez fizik tedaviye gidiyor ve sağlık ekibinin iyileşme ve işe geri dönme konusunda tamamen yetkin olduğunu söylüyor. 'Destek ekibine ihtiyacınız var' ve 'Bulunduğunuz yere geri döneceğinize inanan insanlarla kendinizi kuşatın' demektedir. "Kamu spotu reklamı gösteren açıdan incelendiğinde, posterde eli sargılı bir erkeğin fotoğrafına yer verildiği görülmektedir. Görsel kodlar içerisinde erkeğin bir marangozhane içerisinde olduğu ve gülümsediği yansıtılmaktadır. Posterin ortasında ise "Katkı sağlayabilmek, para kazanabilmek ve çalışabilmek için işime geri döndüm" yazılı kodu bulunmaktadır. Yazlı kodlar kutucuklar içerisinde verildiği için sözlerin fotoğraftaki erkeğe ait olduğu anlaşılmaktadır.

Tablo 9. Göstergeler Modeli Bağlamında "Marangoz" Konulu Kamu Spotu Reklamı

\begin{tabular}{|c|c|c|}
\hline Gösterge & Gösteren & Gösterilen \\
\hline İnsan & Marangoz & $\begin{array}{c}\begin{array}{c}\text { Engelli olmak çalışma hayatından tamamen uzaklaşmak anlamına } \\
\text { gelmemektedir }\end{array}\end{array}$ \\
\hline Sağlık & $\begin{array}{l}\text { Bedensel } \\
\text { engel }\end{array}$ & Bedensel engel çalışmaya engel değildir \\
\hline İnsan & Destek ekibi & $\begin{array}{c}\text { Engellilerin çalışma hayatına kolay adapte olabilmesi toplumsal } \\
\text { destek ile mümkündür }\end{array}$ \\
\hline
\end{tabular}

Gösterilen açıdan incelendiğinde, posterde iş hayatında yapılan bir hata veya iş kazası sonucunda insanların engelli durumuna gelebilecekleri, buna karşın engelli bireylerin ailesinden, dostlarından, çalışma arkadaşlarından ve sağlık ekibinden alacakları desteklerle iş yaşamına tekrar dönebilecekleri mesajı verilmektedir. Bu süreçte kamu spotu reklamında toplumsal desteğin engellilerin iş yaşamına tekrar adapte olmalarında önemli bir rolü olduğu üzerinde durulmaktadır. Diğer bir ifadeyle engellilerin çalışma hayatlarına geçişlerinde yalnızca engelli bireylerin değil toplumsal olarak çevresindekilerin de çabalarının olması gerektiği aktarılmaktadır. Kamu spotu reklamında diğer kamu spotu reklamlarından farklı olarak toplumsal desteğin önemi üzerinden engelli istihdamına yönelik teşvik edici mesajlar verilmeye çalışılmıştır.

Resim 8. "Marangoz" Konulu Kamu Spotu Reklamı

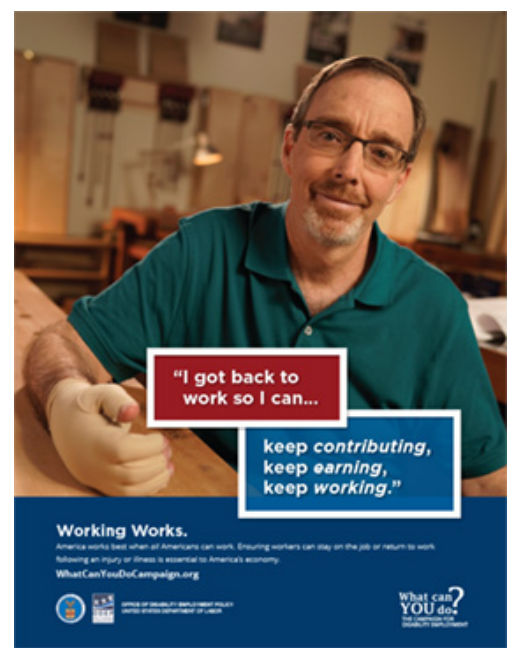




\section{iii) "Gazi" Konulu Kamu Spotu Reklamı}

"Gazi" konulu kamu spotu reklamında yer alan Ish Escobar ile ilgili şu bilgilere yer verilmektedir; "Kaliforniyalı Ish Escobar, şu an yaralı askerler için oluşturulan bir destek ve işe alım programını yönetmektedir. Hizmete bağlı oluşan engellerden dolayı ABD Ordusu'ndan gazi olarak ayrıldı. Ish, sivil işgücüne geçiş aşamasında ihtiyaç duyduğu desteği sağladığı için işverenine çok şey borçlu olduğunu hissetmektedir. Virginia'da eşi ve dört çocuğu ile yaşıyor. Ish, 'Iş̧ benim için çok önemli, üretken olmak istedim, aileme katkı sağlamak istedim' demektedir. "Kamu spotu reklamı gösteren açıdan incelendiğinde, posterde bir erkek ile bir köpeğin fotoğrafına yer verildiği görülmektedir. Görsel kodlar içerisinde erkeğin gülümsediği yansıtılmaktadır. Posterin ortasında ise "Sorun işe başlamam değil, nasıl ve ne zaman başlamamdı" yazılı kodu bulunmaktadır. Yazlı kodlar kutucuklar içerisinde verildiği için sözlerin fotoğraftaki erkeğe ait olduğu anlaşılmaktadır.

Tablo 10. Göstergeler Modeli Bağlamında "Gazi" Konulu Kamu Spotu Reklamı

\begin{tabular}{ccc}
\hline Gösterge & Gösteren & Gösterilen \\
\hline İnsan & Gazi & Gaziler de çalışma hayatına katkı sağlayabilmektedir \\
\hline İnsan & Gazinin ailesi & $\begin{array}{c}\text { Engelliler kimi zaman ailelerine katk1 sağlamak için } \\
\text { çalışabilmektedir }\end{array}$ \\
\hline İnsan & İşveren & Engellilerin çalışma hayatına kazandırılmasında işverenler önemli \\
rol oynamaktadır
\end{tabular}

Resim 9. "Gazi" Konulu Kamu Spotu Reklamı

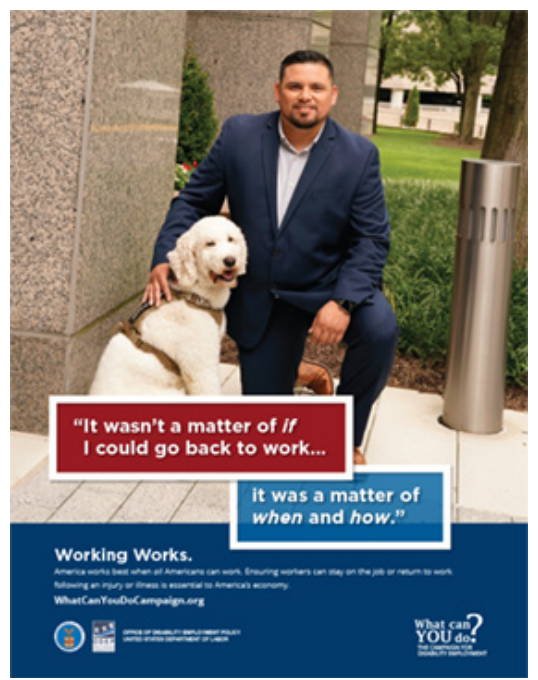

(Kaynak: CDE, 2018)

Gösterilen açıdan incelendiğinde, posterde engelli bireylerin kimi zaman ailelerine katkı sağlamak için çalıştıkları ve bu yüzden de iş yaşamında yer aldıkları aktarılmaya çalışılmaktadır. Ayrıca kamu spotu reklamında işverenlerin engelli istihdamında önemli bir rolü olduğu üzerinde de durulmaktadır. Posterde engelli bireylerin çalışma hayatında yer almalarının bazen toplumsal bir gereklilik olduğu üzerinde durulmakta, bu nedenle engelli istihdamında işverenlerin gerekli sorumlulukları yerine getirmeleri istenmektedir. Engelli 
bireylerin iş yaşamına adapte edildiklerinde verimli bir şekilde çalışabildikleri ve aile ekonomilerine de katkı sağlayabildikleri mesajı verilmektedir. Bu nedenle kamu spotu reklamlarında doğrudan işverenlerin engelli istihdamını teşvik etmesi istenmektedir.

\section{SONUÇ}

Çalışma kapsamında incelenen "Kimim", "Yapabilirim", "İşler" isimli üç reklam kampanyasında da iş hayatında başarılı olan engelli bireylerin konu edinildiği görülmektedir. Böylece reklam kampanyasında başarılı örnekler üzerinden engelli bireylerin istihdama katılımlarının teşvik edilmesi amaçlanmıştır. Genel olarak reklam kampanyalarında verilen ortak mesaj, bedensel ve zihinsel engellerin çalışmaya engel olmadığı yönündedir. Kampanyalarda yer alan kamu spotu reklamlarında farklı toplumsal sınıftan, farklı engellere sahip bireyler ön plana çıkarılmakta ve çalışma hayatlarında engellerini nasıl aştıkları aktarılmaktadır. $\mathrm{Bu}$ yolla engelli bireylerin zihinlerinde "çalışamam" algısının ortadan kaldırılması ve iş hayatına dâhil edilmeleri amaçlanmıştır. Çalışma kapsamında incelenen tüm kamu spotu reklamlarındaki görsel kodlarda engelli bireylerin çalışmaktan mutlu oldukları aktarılmıştır. Böylece çalışma hayatı, engelli bireyler için bir zorunluluk olarak değil aksine toplumsal hayata katılımın önemli bir aracı olarak yansitılmıştır.

"Kimim" ve "Yapabilirim" isimli reklam kampanyalarında engelli istihdamında en önemli aşamanın engelli bireylerin çalışma isteklerinin arttırılması olduğu aktarılmıştır. Bu açıdan farklı engellere sahip engelli bireylerin iş yaşamına ne şekilde adapte oldukları aktarılarak, engelliler üzerinde çalışmaya yönelik istek uyandırılması istenmiştir. Diğer yandan engelli bireylerin yalnızca engelleri üzerine odaklanarak "engelliler çalışamaz", "engellilerden istenilen iş verimi sağlanmaz", "engelliler her işi yapamaz" şeklinde oluşturulan olumsuz algıların ortadan kaldırılması amaçlanmıştır. Bu amaçla engelli bireylerin engellerinin farklı fiziksel ve sosyal rolleri içerisinde yalnızca sınırlı bir özellikleri olduğu vurgulanmış ve engelleri üzerinden engelli bireyler hakkında genellemelerin yapılmaması istenmiştir. "İşler" isimli reklam kampanyasında da engelli istihdamında işverenlerin, ailenin, dostların ve sağlık ekibinin önemli bir rol oynadığı üzerinde durulmuştur. $\mathrm{Bu}$ açıdan engelli bireylerin istihdama katılmasında tüm paydaşların ortak hareket etmesi gerektiği vurgulanmıştır.

Çalışma kapsamında incelenen reklam kampanyalarında verilmek istenen mesajların, engellilerin istihdamını teşvik etmede önemli bir rol oynadığı söylenebilmektedir. Özellikle engellilerin çalışmalarını engelleyecek olan olumsuz algıların ve yorumların ortadan kaldırılmasında, engelli bireylerin çalışma isteklerinin arttırılmasında ve işverenlere engelli istihdamındaki gerekli sorumluluklarının hatırlatılmasında reklam kampanyaları oldukça önem taşımaktadır. Diğer yandan reklam kampanyalarında doğrudan günlük hayattan engelli bireylere yer verilmesi de reklamda verilmek istenen mesajın güvenilirliğini ve inandırıcılığını attırmaktadır. Tüm bunlara karşın yalnızca engelli istihdamında olumlu örnekler üzerinden mesajların verilmesi ve engelli istihdamında yaşanan teknik alt yapı eksikliği, yardımcı cihaz sıkıntısı vb. konulara vurgu yapılmaması da reklam kampanyalarında sınırlı bir etkinin oluşmasına yol açmaktadır.

ABD Çalışma Bakanlığı'nın 2018 yılı verilerine göre ülkede bulunan engellerinin \%79,2'si herhangi bir işte çalışmamakta, \%1,7'si işsiz olarak değerlendirilmektedir. Engelli istihdamı ise \%19,1 olarak belirtilmektedir. Bu oran ABD'deki engelli istihdamında son 9 yılda yaşanan en yüksek değeri ifade etmektedir (DOL, 2018). Bu açıdan ABD Çalışma Bakanlığı'nın istatistiski verileri özelinde değerlendirildiğinde, ABD'de yayınlanan engelli 
istihdamını konu alan kamu spotu reklamlarının engelli istihdamında artışın oluşmasında rolü olduğu söz edilebilmektedir.

ABD Çalışma Bakanlığı'nın engelli istihdamına yönelik hazırlanan "Ne yapabilirsin?" isimli reklam kampanyası çalışma kapsamında incelenmiştir. ABD özelinde yapılan çalışmada elde edilen bulgular ile engelli istihdamını teşvik etmede reklam kampanyalarının ne gibi bir rol oynadığı ve engelli bireylerin kamu spotu reklamlarında nasıl temsil edildiği ortaya konulmaya çalışılmıştır. Çalışma incelediği konu bakımından alana katkı sağlamakla birlikte, kamu spotu reklamlarının engelli istihdamında gerek engelli bireyler gerekse işverenler üzerinde ne gibi bir etki bıraktığını ortaya koyamamaktadır. $\mathrm{Bu}$ açıdan gelecek çalışmaların engelli istihdamını konu alan kamu spotu reklamlarının kitleler üzerindeki etkisini araştıran saha çalışmalarına yönelmesinin alana katkı sağlayacağı düşünülmektedir.

\section{Kaynakça}

Aakvik, A. (2003). Estimating the Employment Effects of Education for Disabled Workers in Norway. Empirical Economics. 28(3). 515-533. doi: 10.1007/s001810200143.

Akova, S. (2017). Sigarayı Birak, Hayatı Birakma" Sloganlı Kamu Spotları Örneklemlerinin Alımlama Analizi Yöntemi ile İncelenmesi. Stratejik ve Sosyal Araştırmalar Dergisi. 1(2). 15-36. doi: 10.30692/sisad. 362259

Arpa, M. \& Çakı, C. (2018). İş Kazalarını Konu Alan İş Güvenliği Reklamlarında Duygusal Çekiciliklerin Kullanımı: Avustralya ve Singapur İş Güvenliği Reklamları Üzerine İnceleme. SGD-Sosyal Güvenlik Dergisi. 8(2). 153-172. doi: 10.32331/sgd.493020.

Arpa, M. (2018). İş Güvenliğini Konu Alan Kamu Spotu Reklamlarında Korku Çekiciliği Kavramının Kullanılması. Uluslararası Sosyal Bilimler Dergisi. 1(2). 105-115.

Aytekin, H. (2016). Görsel-İşitsel Medyada Sağlık - Güvenlik Halleri: Tartışılması Gereken Bir Alan Olarak Kamu Spotu. Selçuk Üniversitesi İletişim Fakültesi Akademik Dergisi. 9(3). 249-275. doi: 10.18094/si.37556

Bayraktaroğlu, G. ve İlter, B. (2007). Sosyal Pazarlama: Engeller ve Öneriler. Ege Akademik Baklş. 7(1). 117-132.

Bara, M. A. (2013). Educational and Career Counseling to People with Disabilities. Polish Journal of Management Studies. 133-139.
Bound, J. \& Waidmann, T. (2002). Accounting for Recent Declines in Employment Rates Among Working-Aged Men and Women with Disabilities. The Journal of Human Resources. Vol. 37. No. 2 (Spring, 2002). pp. 231-250. doi: $10.2307 / 3069646$

Burchardt, T. (2005). The Education and Employment of Disabled Young People: Frustrated Ambition (Vol. 565). The United Kingdom: Policy Press.

CDE (2018). Amerikan Çalışma Bakanlığının Engelli İstihdamına Yönelik Kamu Spotu Reklamları. [ https://www.whatcanyoudocam paign.org/ ]. (Erişism: 13.02.2019).

Csikszentmihalyi, M.,\& Csikszentmihalyi, I. (1975). Beyond Boredom and Anxiety (Vol. 721). The United States of America: JosseyBass.

Çakar, C. (2017). İdeolojik Bir Alan Olarak Kamu Spotu ve İktidar. İstanbul Bilgi Üniversitesi. Sosyal Bilimler Enstitüsü Yayımlanmamış Yüksek Lisans Tezi. İstanbul.

Çak1, C. \& Gülada, M. (2018). The Representation of Muslims in Public Spot Advertisements Against Islamophobia: The Case of USA. Canada and the Netherlands. Medya ve Din Araştırmaları Dergisi. 1(2). 243254.

Çavuş, Ö. H. \& Tekin, A. (2015). Türkiye'de Engellilerin İstihdam Yöntemi Olarak Korumalı İşyeri. Dokuz Eylül Üniversitesi İktisadi ve İdari Bilimler Fakültesi Dergisi. 30(1). 145165. 
De Saussure, Ferdinand. (2014). Genel Dilbilim Yazıları. (Çev., Savaş Kılıç). İstanbul: İthaki Yayınları.

DOL (2018). 2018 ABD Engelli İstihdamı İstatistiği. [https:// www. dol. gov/ odep/ topics/ Disability Employment Statistics.htm]. (Erişim: 01.08.2019).

DOL (2019a). ABD Çalışma Bakanlığ Verilerine göre ABD'deki Engelli İstihdam Oran1. [https://www.dol.gov/odep/topics/ disabilityemploymentstatistics.htm]. (Erişim: 16.02.2019).

DOL (2019b). ABD Çalışma Bakanlığı Verilerine Göre Gazi İstihdam Oranı. [https://www. dol. gov/ vets/]. (Erişim: 17.02.2019).

DOL (2019c). ABD Çalışma Bakanlığı Verilerine Göre Siyahi Bireylerin İstihdam Oran1. [ https:// www. bls. gov/ careeroutlook/ 2018/ article/ blacks -in-the- labor- force.htm. ]. (Erişim: 17.02.2019).

Dooley, D., Fielding, J., \& Levi, L. (1996). Health and Unemployment. Annual Review of Public Health, 17(1). 449-465.

EYH (2018). Engelli ve Yaşlı Bireylere İlişkin İstatiksel Bilgiler. [https://eyh. aile. gov. tr/uploads/ pages/ engelli- ve- yasli- bireylere iliskin- istatistiki- bilgiler ]. (Erişim: 05.02.2019).

Fidan, F., Yeşil, Y. (2018). Engelli Çocukların Eğitimi ve İstihdama Katılımı: Nilüfer İş Okulu Örneği. Journal of Current Researches on Educational Studies. 8(2). 1-10.

Fiske, J. (2017). İletişim Çalışmalarına Giriş. (Çev: Süleyman İrvan). 5. Basım. Ankara: Bilim ve Sanat Yayınları.

Gazi, M. \& Çakı, C. (2018). Siyahi Ayrımcılığa Karşı Hazırlanan Kamu Spotu Reklamları. International Journal of Labour. Life and Social Policy. 1(2). 48-62.

Genç, Y., \& Çat, G. (2013). Engellilerin İstihdamı ve Sosyal İçerme İlişkisi. Akademik İncelemeler Dergisi. 8(1). 363-393.
Güngör, N. (2013). Illetișim Kuramlar ve Yaklaşımlar. 2. Baskı. İstanbul: Siyasal Kitapevi.

Hüseyinli, N., Göçmen, S., Nasibov, D. (2017). Çalışma Hayatında Engelli Haklarına İlişkin Yasal Düzenlemeler ve Engellilerin Haklara İlişkin Farkındalıkları. İnsan ve Toplum Bilimleri Araştırmaları Dergisi. 6(6). 138-152.

ISKUR (2018). Engelli Bireylerin İstidam İstatiksel Bilgileri. [https://www.iskur.gov.tr/ isveren/engelli-istihdami/ ]. (Erişim: 06.02.2019).

Kalkan Kocabay, H. (2008). Tiyatroda Göstergebilim. İstanbul: E Yayınları.

Lee, N. R., \& Kotler, P. (2011). Social Marketing: Influencing Behaviors for Good. The United States of America: Sage Publications.

Köksal, A. (2010). Türkiye'de Engelli İstihdamı ve Bir Araștırma. Yayınlanmamıș Yüksek Lisans Tezi. Bahçeşehir Üniversitesi Sosyal Bilimler Enstitüsü İnsan Kaynakları Yönetimi. İstanbul.

Uslu, A. O., \& Güneş, M. (2017). Engelsiz Kentler-Herkes İçin Erişilebilir Kentler. Uluslararası Peyzaj Mimarlı̆̆ Araştırma Dergisi. 30-36.

Rifat, M. (2013). Açıklamalı Göstergebilim Sözlügü: Kavramlar, Yöntemler, Kuramcllar, Okullar. İstanbul: Türkiye İş Bankası Kültür Yayınları.

RTÜK (2012). Kamu Spotları Yönergesi. [https://www.rtuk.gov.tr/kamu-spotlari/5029/ 3985/kamu-spotlari-yonergesi.html]. (Erişim: 06.02.2019).

Rudgers (2016). Workforce Policies for Disadvantaged Populations. [http:// heldrich. rutgers. edu/ research/ products/ researchpublications-eports? tid_2\% 5B\%5D= 41\&tid_1 =All\&keys =\&keys_1 $=\&$ tid\% 5B\%5 $\mathrm{D}=25]$. (Erişim: 03.02.2019).

Schur, L.(2002). The Difference a Job Makes: The Effects of Employment Among People with Disabilities. Journal of Economic Issues. 36(2). 339-347. doi: 10.1080/00213624.2002.11506476. 
Seyyar, A. (2000). Uluslararası Boyutuyla Özürlü Kota Sistemi. Kamu-İ̧ Dergisi. S 1.

Sığırc1, İ. (2016). Göstergebilim Uygulamaları, Metinleri, Görselleri ve Olayları Okuma. Ankara: Seçkin Yayıncılık.

Şen, D. (2018). Tedavi Edici Sağlık Hizmetlerinin Geliştirilmesinde Kamu Spotları. International Anatolia Academic Online Journal / Social Science Journal. 4(1). 58-75.

Talas, C. (2015). Çalışma Hakkı ve Türkiye'deki Durum. Ankara Üniversitesi SBF Dergisi. 46(1). 407-421.

Tekinalp, Ş. \& Uzun, R. (2013). Illetişim Araştırmaları ve Kuramları. 4. Baskı. İstanbul: Derin Yayınları.

Zaim Gökbay, İ., Ergen, A., Özdemir, N. (2012). Engelli Bireylerin İstihdamına Yönelik Bir Vaka Çalışması: Engelsiz Eğitim. Öneri Dergisi. 9(36). 1-8. 
